\title{
Improving the Stability of the EC1 Domain of E-cadherin by Thiol Alkylation of the Cysteine Residue
}

\author{
Maulik Trivedi $^{1}$, Jennifer S. Laurence ${ }^{1}$, Todd D. Williams ${ }^{2}$, C. Russell Middaugh ${ }^{1}$, and \\ Teruna J. Siahaan ${ }^{1,3}$ \\ 1'Department of Pharmaceutical Chemistry, The University of Kansas, 2095 Constant Ave., \\ Lawrence, Kansas 66047 \\ ${ }^{2}$ Mass Spectrometry Service Laboratory, The University of Kansas, Lawrence, KS 66047
}

\begin{abstract}
The objective of this work was to improve chemical and physical stability of the EC1 protein derived from the extracellular domain of E-cadherin. In solution, the EC1 protein has been shown to form a covalent dimer via a disulfide bond formation followed by physical aggregation and precipitation. To improve solution stability of the EC1 protein, the thiol group of the Cys 13 residue in EC1 was alkylated with iodoacetate, iodoacetamide, and maleimide-PEG-5000 to produce thioether derivatives called EC1-IA, EC1-IN, and EC1-PEG. The physical and chemical stabilities of the EC1 derivatives and the parent EC1 were evaluated at various $\mathrm{pHs}$ (3.0, 7.0, and $9.0)$ and temperatures $\left(0,3,70{ }^{\circ} \mathrm{C}\right)$. The structural characteristics of each molecule were analyzed by circular dichroism (CD) and fluorescence spectroscopy and the derivatives have similar secondary structure as the parent EC1 protein at $\mathrm{pH}$ 7.0. Both EC1-IN and EC1-PEG derivatives showed better chemical and physical stability profiles than did the parent EC1 at pH 7.0. EC1PEG had the best stability profile compared to EC1-IN and EC1 in solution under various conditions.
\end{abstract}

\author{
Keywords \\ E-cadherin; EC1 domain; Pegylation; Thiol acetylation; Physical stability; Chemical stability
}

\section{INTRODUCTION}

E-cadherin is a calcium-binding glycoprotein found at the adherens junction of the intercellular junctions of the intestinal mucosa (Zheng et al., 2006). It is one of the important proteins that mediate cell-cell adhesion at the intercellular junctions. Modulation of cadherin interactions at the intercellular junctions by cadherin peptides improves the delivery of paracellular marker molecules (i.e., ${ }^{14} \mathrm{C}$-mannitol) and anticancer drugs (i.e., $3 \mathrm{H}$ daunomycin) through the blood-brain barrier (Kiptoo et al., 2011). The EC1 domain of Ecadherin has an important role in the selectivity of homophilic E-cadherin interactions as well as in the heterophilic interaction of E-cadherin with $\alpha_{\mathrm{E}} \beta_{7}$ integrin to create cell-cell

\footnotetext{
(C) 2012 Elsevier B.V. All rights reserved.

${ }^{3}$ Address correspondence to: Dr. Teruna J Siahaan, Department of Pharmaceutical Chemistry, The University of Kansas, 2095 Constant Avenue, Lawrence, Kansas 66047, Phone: 785-864-7327, Fax: 785-864-5736, siahaan@ ku.edu.

Publisher's Disclaimer: This is a PDF file of an unedited manuscript that has been accepted for publication. As a service to our customers we are providing this early version of the manuscript. The manuscript will undergo copyediting, typesetting, and review of the resulting proof before it is published in its final citable form. Please note that during the production process errors may be discovered which could affect the content, and all legal disclaimers that apply to the journal pertain.
} 
adhesion (Pokutta et al., 2008; Pokutta and Weis, 2007; Shiraishi et al., 2005; Zheng et al., 2006). To study the biological function of the EC1 domain to modulate cell-cell adhesion at the intercellular junctions of the intestinal mucosa, we expressed the recombinant human $\mathrm{EC} 1$ protein. Unfortunately, the EC1 protein is unstable during storage (i.e., 4 weeks at 4 ${ }^{\circ} \mathrm{C}$ ) after purification. It produces a covalent dimer (EC1-s-s-EC1) via an intermolecular disulfide bond between the only Cys residue (Cys13) in the monomer, and the formation of a covalent dimer induces the generation of oligomers and precipitation (Makagiansar et al., 2002b; Trivedi et al., 2009). The presence of the covalent dimer and physical oligomers has been characterized using SDS-PAGE and size-exclusion chromatography (SEC) as well as by monitoring changes in its far UV circular dichroism (CD) spectra and intrinsic fluorescence emission spectra after storage at $4{ }^{\circ} \mathrm{C}$. The presence of precipitates prevents long-term storage and interferes with the study of the biological activity of EC1 as an inhibitor of cell-cell adhesion. Therefore, it is necessary to find a suitable method to improve the storage stability of this protein for its use in future biological activity evaluations in inhibiting cell-cell adhesion.

Accelerated stability studies at different $\mathrm{pH}$ values (3.0, 7.0, and 9.0) and temperatures (37 ${ }^{\circ} \mathrm{C}$ and $70{ }^{\circ} \mathrm{C}$ ) have shown that the $\mathrm{EC} 1$ protein also undergoes hydrolysis at the D93-P94 peptide bond (Trivedi et al., 2009). Molecular dynamics simulation studies have indicated that the covalent dimer has a higher dynamic mobility than the monomer, thereby contributing to the instability of the protein (Trivedi et al., 2009). The increased flexibility of the EC1 dimer could explain the susceptibility of the D93P94 peptide bond to hydrolysis and physical oligomerization. It is interesting to find that chemical and physical degradation can be inhibited by addition of dithiothreitol (DTT) as a reducing agent to prevent the formation of a covalent dimer. However, the presence of reducing agents (i.e., DTT or glutathione) would be undesirable during biological activity studies (i.e., inhibition of cellcell adhesion) of EC1 since they may affect the results of the cell adhesion assays. Thus, an alternative method is needed to stabilize the monomeric form of the EC1 protein so it can be evaluated in biological assays and stored for long periods of time.

To eliminate the possibility of covalent dimerization of the EC1 protein, the thiol group of the Cys13 residue in EC1 was alkylated to produce thioether derivatives called EC1-IA, EC1-IN, and EC1-PEG (Fig. 1). To produce EC1-IA and EC1-IN, the thiol group of EC1 was reacted with iodoacetic acid and iodoacetamide, respectively; this method has been extensively applied to modify protein (Dickens, 1933; Smythe, 1936). Next, the EC1 protein was derivatized with polyethylene glycol-5000 (PEG5000) to prepare EC1-PEG by reacting the Cys13 thiol group with the maleimide group on the PEG5000 (Bell et al., 2008; Colonna et al., 2008). The physical and chemical stabilities of the EC1 derivatives were compared to those of the parent EC1 and evaluated at various pHs (3.0, 7.0, and 9.0) and temperatures $(0$, $37,70^{\circ} \mathrm{C}$ ). The structural characteristics of EC1 derivatives during the stability studies were analyzed by circular dichroism (CD) and fluorescence spectroscopy (Trivedi et al., 2009). The stability of both EC1-IN and EC1-PEG derivatives was better than that of the parent EC1 at pH 7.0. Compared to EC1-IN and EC1, the EC1-PEG had the best stability profile under various conditions.

\section{EXPERIMENTAL METHODS}

\section{Production of EC1-IA and EC1-IN}

The EC1 protein $($ M.W. = 11,628 Da) was expressed in E. coli and purified in the presence of $\beta$-mercaptoethanol (BME) (Makagiansar et al., 2002a; Makagiansar et al., 2002B). The $\mathrm{EC} 1$ protein $(0.2 \mathrm{mg} / \mathrm{mL})$ was reacted in the dark with iodoacetate or iodoacetamide (1.0 $\mathrm{mM}$ ) for $4 \mathrm{~h}$ at $\mathrm{pH} 8.0$ in a buffer containing $0.02 \mathrm{mM}$ BME, $20 \mathrm{mM}$ Tris, and $4.0 \mathrm{M}$ guanidine hydrochloride $(\mathrm{Gdn} . \mathrm{HCl})$. The completion of the reaction was monitored and 
confirmed by matrix-assisted laser desorption/ionization (MALDI) mass spectrometry with time-of-flight (TOF) detection. The alkylated EC1 (EC1-IA and EC1-IN) was refolded by employing a stepwise dilution method in which the concentration of $\mathrm{Gdn} . \mathrm{HCl}$ was reduced from $4.0 \mathrm{M}$ to $0.5 \mathrm{M}$ with a $0.5 \mathrm{M}$ decrease in each dilution step. The dilution step consists of the addition of an appropriate volume of a buffer containing $20 \mathrm{mM}$ Tris at $\mathrm{pH} 8.0$, followed by incubation at $4{ }^{\circ} \mathrm{C}$ for $8 \mathrm{~h}$. When the $\mathrm{Gdn} . \mathrm{HCl}$ concentration reached $0.5 \mathrm{M}$, dialysis was performed with an $8-\mathrm{kD}$ membrane to remove the $\mathrm{Gdn} . \mathrm{HCl}, \mathrm{BME}$, and the unreacted iodoacetate or iodoacetamide. Far UV CD spectroscopy was used to determine the success of protein refolding.

\section{Production of EC1-PEG}

Maleimide-PEG (250 mg, MW = 5,000 Da, Sigma Chemical Co., St. Louis) was added to $50 \mathrm{~mL}$ of $20 \mathrm{mM}$ Tris buffer at $\mathrm{pH} 8.0$ containing $0.2 \mathrm{mg} / \mathrm{mL}$ of EC1 and $0.2 \mathrm{mM}$ DTT. The reaction mixture was incubated for $2 \mathrm{~h}$ at $22{ }^{\circ} \mathrm{C}$ followed by injection of $50 \mu \mathrm{L}$ of the solution to MALDI-TOF MS analysis. The remaining solution was concentrated to $10 \mathrm{~mL}$ by passing it through a 10,000 Da cutoff membrane in an Amicon centrifuge tube and centrifuging at $4000 \times \mathrm{g}$. The concentrated solution was stored at $4{ }^{\circ} \mathrm{C}$ until it was purified by SEC.

Three $\mathrm{mL}$ of the above concentrated solution was injected into a Superdex 200 sizeexclusion column with a mobile phase of $20 \mathrm{mM}$ Tris buffer at $\mathrm{pH} 8.0$ and a flow rate of 0.5 $\mathrm{mL} / \mathrm{min}$. The EC1-PEG conjugate, parent EC1, and the maleimide-PEG were detected as separate peaks in the SEC chromatogram by their UV absorbance at 220 or $280 \mathrm{~nm}$, and the yield of EC1-PEG was 75\%. The column volume was $150 \mathrm{~mL}$, and the volume of each collected fraction was $3.0 \mathrm{~mL}$. The EC1-PEG fractions were pooled and concentrated to 7.5 $\mathrm{mL}$. The concentration of EC1-PEG in this final solution was equal to $86 \mu \mathrm{M}$ of EC1. Fifty $\mu \mathrm{L}$ of this EC1-PEG solution was analyzed by MALDI-TOF. The remaining EC1-PEG was used for chemical stability studies using high performance liquid chromatography (HPLC) analysis and structural studies using far CD spectroscopy and intrinsic fluorescence emission spectroscopy.

\section{Chemical stability studies of EC1-IN and EC1-PEG}

The EC1-IN and EC1-PEG proteins were dialyzed into $\mathrm{pH} 3.0,7.0$, and 9.0 buffers and incubated at a concentration of $86 \mu \mathrm{M}$ in sealed vials at 4,37 , and $70^{\circ} \mathrm{C}$ for $4 \mathrm{~h}$ (Trivedi et al., 2009). The buffers used were $100 \mathrm{mM}$ phosphate for $\mathrm{pH} 3.0,50 \mathrm{mM}$ phosphate for $\mathrm{pH}$ 7.0 , and $100 \mathrm{mM}$ borate containing $0.08 \mathrm{M} \mathrm{NaCl}$ for $\mathrm{pH} 9.0$. Samples were drawn at $0,0.5$, $1.0,2.0$, and $4.0 \mathrm{~h}$ and immediately stored at $-70{ }^{\circ} \mathrm{C}$ until subsequent HPLC analysis was performed. The HPLC was equipped with a C18 column (Varian Microsorb; pore-size: 300 $\AA$; dimensions $250 \times 4.6 \mathrm{~mm})$ for separation of the analytes. The protein solution $(25 \mu \mathrm{L})$ was injected into the column and eluted at a rate of $1.0 \mathrm{~mL} / \mathrm{min}$. A gradient elution method incorporating solvent A (94.9\% double distilled water, $5 \%$ acetonitrile (ACN), and $0.1 \%$ TFA) and solvent $\mathrm{B}(100 \% \mathrm{ACN})$ was used. The gradient elution followed the sequence $0 \%$ to $45 \% \mathrm{~B}$ from 0.0 to $2.0 \mathrm{~min}, 45 \%$ to $51 \% \mathrm{~B}$ from 2.0 to $12.0 \mathrm{~min}$, at $51 \% \mathrm{~B}$ from 12.0 to $17.0 \mathrm{~min}, 51 \%$ to $100 \% \mathrm{~B}$ from 17.0 to $19.0 \mathrm{~min}$, at $100 \% \mathrm{~B}$ from 19.0 to $21.0 \mathrm{~min}$, and $100 \%$ B back down to 0\% B from 21.0 to 22.0 min. A Varian Prostar UV detector at a wavelength of $220 \mathrm{~nm}$ was used to detect the proteins eluted from the column. MALDI-TOF MS analysis was used to determine the molecular weight of any new peaks observed on the HPLC chromatogram.

\section{Physical stability studies}

Physical stability studies of EC1-IN and EC1-PEG were performed by monitoring the far UV CD spectra and the intrinsic fluorescence emission spectra at days 0,14 , and 28 of 
incubation at $4{ }^{\circ} \mathrm{C}$ and $\mathrm{pH} 3.0,7.0$ and 9.0. The concentrations and buffers used were the same as described in the chemical stability studies section.

Far UV CD studies-The secondary structural changes of the EC1-IN or EC1-PEG protein were analyzed by far UV CD spectroscopy with a Jasco spectropolarimeter (J-720) equipped with a Peltier temperature controller by loading $300 \mu \mathrm{L}$ of the protein into a sealed CD cuvette with $0.1 \mathrm{~cm}$ pathlength (Derrick et al., 2004; Zheng et al., 2009a; Zheng et al., 2009b). The protein CD spectrum was measured at $10^{\circ} \mathrm{C}$ between 200 and $250 \mathrm{~nm}$.

Triplicate spectra were obtained for EC1-IN or EC1-PEG, and the contribution of the buffer was eliminated by subtracting the blank spectrum (containing buffer alone) from the spectrum of protein in the same buffer. The same samples were also used for the thermal unfolding studies by recording their $\mathrm{CD}$ spectra at every $5^{\circ} \mathrm{C}$ increase in temperature. The temperature of the cuvette holder was increased from $10^{\circ} \mathrm{C}$ to $65^{\circ} \mathrm{C}$ at a rate of $15^{\circ} \mathrm{C} / \mathrm{h}$. The samples were equilibrated at the target temperature for $300 \mathrm{~s}$ before obtaining their spectra. The entire procedure was repeated after 14 and 28 days for samples stored at $\mathrm{pH}$ 3.0, 7.0, and 9.0 at $4{ }^{\circ} \mathrm{C}$. The ellipticity at $218 \mathrm{~nm}$ (used to monitor changes in the $\beta$-sheet content) was plotted against the corresponding temperature, and a sigmoidal function was used to fit the thermal unfolding curves using Origin 7.0 software. The midpoint of each transition in the sigmoidal fit was defined as the thermal unfolding temperature $\left(\mathrm{T}_{\mathrm{m}}\right)$.

Intrinsic fluorescence emission studies-Changes in the tertiary structure of EC1-IN and EC1-PEG after 14 and 28 days incubation at $4{ }^{\circ} \mathrm{C}$ and different $\mathrm{pH}$ values $(3.0,7.0$, or 9.0) were monitored using fluorescence spectroscopy and compared to the emission profile on day 0 . For each experiment, $90 \mu \mathrm{L}$ of the protein $(86 \mu \mathrm{M})$ was diluted to $0.9 \mathrm{~mL}$ with the appropriate buffer and transferred to a quartz fluorescence cuvette. The protein was excited at $295 \mathrm{~nm}$ (>95\% Trp emission), and the fluorescence emission was observed between 305 and $405 \mathrm{~nm}$ using a PTI QuantaMaster spectrofluorometer (Rexroad et al., 2003; Zheng et al., 2009a; Zheng et al., 2009b). Emission was set between 500,000 and 1,000,000 counts/ sec by adjusting the excitation and emission slits. The emission spectra were obtained in triplicate, and the blank spectrum was subtracted from each of them. Thermal unfolding of EC1-IN and EC1-PEG was studied at $\mathrm{pH} 3.0,7.0$, and 9.0 by increasing the temperature of the cuvette chamber from $10^{\circ} \mathrm{C}$ to $87.5^{\circ} \mathrm{C}$ at a rate of $15^{\circ} \mathrm{C} / \mathrm{h}$; the emission spectra were recorded at every $2.5^{\circ} \mathrm{C}$ increase in temperature. Each fluorescence emission spectrum obtained was fitted to an extreme asymmetric peak function using the non-linear curvefitting wizard of Origin 7.0 software to obtain the wavelength of maximum emission. After subtracting the blank emission signal from each spectrum, the wavelength of maximum emission at each temperature point was plotted against the corresponding temperature. This plot, which provided the thermal unfolding profile of the protein, was then fitted to a sigmoidal function using Origin 7.0 software.

\section{RESULTS}

\section{Alkylation of the thiol group of EC1}

The alkylation of EC1 with iodoacetate and iodoacetamide (Fig. 1) produced the desired EC1-IA and EC1-IN in quantitative yields with one band in an SDS PAGE gel and a single peak on a reversed-phase HPLC C18 column. MALDI mass spectra showed the addition of acetate and acetamide groups in EC1-IA (MW = 11,686.6 Da) and EC1-IN (MW = 11,685.3 $\mathrm{Da})$, respectively. The reaction between $\mathrm{Cys}$ thiol of $\mathrm{EC} 1$ and maleimide-PEG produced EC1-PEG in 75\% yield, and the desired EC1-PEG was separated from the EC1 and PEG by SEC. Using a C18 reversed-phase column, EC1-PEG showed a single peak at $8.1 \mathrm{~min}$ compared to EC1 at $8.4 \mathrm{~min}$ and maleimide-PEG at $7.9 \mathrm{~min}$. The MALDI spectrum of EC1- 
PEG showed a broad peak centered around MW of 16,927 due to a distribution of molecular weights of the PEG group around 5,000 Da.

The CD spectra of EC1-IA and EC1-IN were compared with that of EC1. The EC1-IN protein has a spectrum identical to that of $\mathrm{EC} 1$ at $\mathrm{pH} 7.0$ with a minimum at $216 \mathrm{~nm}$ and maxima at 235 and $205 \mathrm{~nm}$ (Fig. 2). However, the CD spectra of EC1-IA at various $\mathrm{pH}$ values showed that this protein was not properly folded (data not shown); thus, it was not investigated further for the stability studies. The secondary structure of EC1-IN is sensitive to $\mathrm{pH}$ changes, indicated by the CD spectra of EC1-IN at $\mathrm{pH} 3.0,7.0$, and 9.0 (Fig. 2). The minimum at $216 \mathrm{~nm}$ at $\mathrm{pH} 7.0$ shifted to $210 \mathrm{~nm}$ at $\mathrm{pH} 3.0$ and 9.0. Furthermore, the spectra at pH 3.0 and 9.0 lack the maxima at 205 and $235 \mathrm{~nm}$. These results indicate that EC1-IN has a secondary structure similar to that of the parent $\mathrm{EC} 1$ at $\mathrm{pH} 7.0$, but not at $\mathrm{pH} 3.0$ and 9.0.

The CD spectra of EC1-PEG were compared to those of EC1 at $\mathrm{pH} 3.0,7.0$, and 9.0. At $\mathrm{pH}$ 3.0, a minor difference was observed between the spectra of the two proteins (Fig. 3A) in which the spectrum of EC1-PEG had more pronounced positive and negative peaks at 235 $\mathrm{nm}$ and $216 \mathrm{~nm}$, respectively. There was no difference between the spectra of EC1-PEG and $\mathrm{EC1}$ at $\mathrm{pH} 7.0$ (Fig. 3B) and 9.0 (Fig. 3C), suggesting that the PEGylated protein maintains its conformation.

\section{Chemical stability comparison of EC1, EC1-IN, and EC1-PEG}

The chemical stability of the EC1-IN protein was monitored by HPLC after incubation for 4 $\mathrm{h}$ at $4{ }^{\circ} \mathrm{C}$ and $\mathrm{pH} 3.0,7.0$, and 9.0. Under these conditions, there was no observable decrease in the chromatographic peak of the EC1-IN protein and no appearance of a new peak for any degradation product (data not shown). These results indicate that the EC1-IN protein is stable upon incubation for $4 \mathrm{~h}$ at $4{ }^{\circ} \mathrm{C}$ at all three $\mathrm{pH}$ values.

The EC1-IN protein was also chemically stable for 4-h incubation at $37^{\circ} \mathrm{C}$ and $\mathrm{pH} 3.0,7.0$, and 9.0 (Fig. 4A) with no significant change in the area under the peak of EC1-IN and no new peaks representing the degradation products. This result is in contrast to our previous studies on EC1 in which $\mathrm{EC} 1$ was unstable during 4-h incubation at pH 7.0 and 9.0 at $37{ }^{\circ} \mathrm{C}$ with the observed Asp93-Pro94 peptide bond hydrolysis product (Trivedi et al., 2009).

These results imply that the EC1-IN protein is more stable to hydrolytic cleavage than is the parent $\mathrm{EC} 1$ protein at $37^{\circ} \mathrm{C}$.

The EC1-IN protein was also stable for $4 \mathrm{~h}$ at $\mathrm{pH} 7.0$ and 9.0 at $70{ }^{\circ} \mathrm{C}$ (Fig. 4B), which is more stable than the parent EC1 under these conditions. Previously, the EC1 protein was shown to undergo Asp93-Pro94 peptide bond hydrolysis and precipitation under similar conditions (Trivedi et al., 2009). Under pH 3.0 and 4-h incubation at $70{ }^{\circ} \mathrm{C}$, however, a significant decrease in the amount of EC1-IN (to 22\%) was observed, followed by the appearance a new peak with $\mathrm{MW}=10,443.5 \mathrm{Da}$ corresponding to the hydrolysis product at the Asp93-Pro94 peptide bond (Fig. 4B). Moreover, at pH 3.0, the increase in the peak area of the hydrolysis product did not correspond quantitatively to the decrease in the peak area of the EC1-IN protein; this was due to the aggregation that leads to precipitation of the protein.

The chemical stability of EC1-PEG at $70{ }^{\circ} \mathrm{C}$ was compared with that of EC1-IN and EC1 by incubation at $\mathrm{pH}$ 3.0, 7.0, and 9.0 for $4 \mathrm{~h}$ (Fig. 5). At all three $\mathrm{pH}$ values studied, the amount of EC1-PEG did not change substantially after incubation for $4 \mathrm{~h}$ at $70{ }^{\circ} \mathrm{C}$. Moreover, no new peaks appeared in the chromatograms. This suggests that, at high temperature, EC1PEG is stable to precipitation and to chemical degradation reactions such as peptide bond hydrolysis. In contrast, the amount of EC1 remaining in solution was the lowest upon 
incubation at $\mathrm{pH} 3.0$, followed by incubation at $\mathrm{pH} 7.0$ and $\mathrm{pH}$ 9.0. The EC1-IN protein was also more stable than the $\mathrm{EC1}$ protein at $\mathrm{pH} 7.0$ and 9.0; however, it was unstable at $\mathrm{pH} 3.0$.

\section{Physical stability comparison of EC1, EC1-IN, and EC1-PEG \\ Secondary structure studies of EC1 and EC1-IN using CD spectroscopy-The} effect on its physical stability of incubating EC1-IN at pH 3.0, 7.0 and 9.0 at $4{ }^{\circ} \mathrm{C}$ for up to 28 days was studied by observing changes in its $\mathrm{CD}$ spectra and comparing the data to the $\mathrm{CD}$ spectra of the parent $\mathrm{EC} 1$ protein. At $\mathrm{pH} 3.0$, the $\mathrm{CD}$ spectra of the EC1-IN protein did not change after incubation for 14 days (Fig. 6A). The CD spectra of EC1, however, changed from day 0 to day 14 with a shift in the minimum at $216 \mathrm{~nm}$ and disappearance of the maxima at 235 and $205 \mathrm{~nm}$ (Fig. 6A), suggesting an increase in $\beta$-sheet character that could be due to the formation of oligomers. The melting curve of EC1-IN was compared to that of EC1 by monitoring the change in the $\mathrm{CD}$ signal at $218 \mathrm{~nm}$ (Fig. 7A). At pH 3.0, there is a very small difference in the melting curve of EC1-IN after 14-day incubation, whereas a dramatic change is detected in the melting curve of EC1 after 14-day incubation. These data imply that EC1-IN does not undergo changes such as covalent dimerization or physical oligomerization when incubated at $4{ }^{\circ} \mathrm{C}$ for 14 days as does EC1.

At $\mathrm{pH}$ 7.0, the CD spectra of EC1-IN protein did not change upon incubation for 0,14 , and 28 days at $4{ }^{\circ} \mathrm{C}$ (Fig. 6B). On the other hand, incubation of the $\mathrm{EC} 1$ protein under the same conditions produced changes in the $\mathrm{CD}$ spectra after 28 days (data not shown). The melting curves of EC1-IN after incubation for 0, 14, and 28 days did not change, but the melting curves of the EC1 protein showed dramatic changes (Fig. 7B), suggesting that EC1-IN did not undergo physical degradation upon incubation.

At $\mathrm{pH}$ 9.0, CD spectra of the EC1-IN protein after 14 and 28 days incubation showed a dramatic shift of the minimum at $210 \mathrm{~nm}$ to $202 \mathrm{~nm}$, indicating a change in the secondary structure upon incubation (Fig. 6C). Conversely, the CD spectrum of EC1 did not change after incubation for 28 days (data not shown). In general, the melting curve profiles of EC1IN were different from those of EC1 at different days. Although it was not dramatic, the melting curves of both EC1-IN and EC1 showed some change after 28 days of incubation (Fig. 7C).

Thermal unfolding properties of EC1-PEG-To evaluate the effect of PEGylation in $\mathrm{EC} 1$, thermal unfolding profiles from $10{ }^{\circ} \mathrm{C}$ to $65^{\circ} \mathrm{C}$ of EC1-PEG were compared to that of $\mathrm{EC} 1$ at $\mathrm{pH}$ 3.0, 7.0, and 9.0 (Fig. 8). The data obtained for the thermal unfolding transitions were fitted to a sigmoidal function, and the mid-point of each fit was defined as the thermal unfolding temperature $\left(\mathrm{T}_{\mathrm{m}}\right)$. The $\mathrm{T}_{\mathrm{m}}$ values of EC1-PEG and $\mathrm{EC} 1$ at various $\mathrm{pH}$ values were compared. It is clear that the EC1-PEG has a higher $\mathrm{T}_{\mathrm{m}}$ than $\mathrm{EC} 1$ at all $\mathrm{pH}$ values studied, indicating that alkylation of EC1 with PEG group improves the thermal stability of EC1. Both proteins have the highest $\mathrm{T}_{\mathrm{m}}$ value at $\mathrm{pH}$ 7.0.

Tertiary structure properties of EC1-IN and EC1-PEG-The shift in the intrinsic fluorescence emission maximum was monitored to evaluate changes in the microenvironment of the Trp6 and Trp66 residues in the EC1-IN, EC1-PEG, and EC1 proteins upon incubation at $4{ }^{\circ} \mathrm{C}$ in $\mathrm{pH} 3.0,7.0$, and 9.0 for 28 days (Table 1). The Trp emission profiles can provide an indication of the buried or exposed nature of the Trp residues as well as the tertiary structural properties of the protein. At $\mathrm{pH} 3.0$, a blue shift (3.0 $\mathrm{nm}$ ) was observed in the emission spectra of EC1 between day 0 to day 28 , and this blue shift suggests the possibility burial of Trp residues in an apolar environment due to protein aggregation. In contrast, the blue shift in EC1-IN was smaller $(0.7 \mathrm{~nm})$ than that in EC1 at $\mathrm{pH}$ 3.0. At $\mathrm{pH} 7.0$, a large red shift $(6 \mathrm{~nm})$ was observed in the EC1 spectra, and only a 
small blue shift ( $\sim 1.0 \mathrm{~nm})$ was observed in EC1-IN spectra after 28 days incubation. The red shift indicates the exposure the Trp residue(s) to the solvent upon unfolding. Only a small shift was observed for emission maxima $(\sim 1.0 \mathrm{~nm})$ for both EC1 and EC-IN upon incubation for 28 days at $\mathrm{pH}$ 9.0. Using the maximum intensity against temperature, thermal unfolding curves of EC1-IN and EC1 were obtained upon incubation for 0 and 28 days at $4{ }^{\circ} \mathrm{C}$ and $\mathrm{pH}$ 7.0. EC1 had one transition around $35^{\circ} \mathrm{C}$ on day 0 , but displayed two transitions after incubation for 28 days with the first transition at $35^{\circ} \mathrm{C}$ and the second at above $60{ }^{\circ} \mathrm{C}$ with a shift to very high wavelengths $(>375 \mathrm{~nm})$. Overall, the fluorescence data obtained suggest that at $\mathrm{pH}$ 3.0, 7.0 and 9.0, the microclimate of the Trp residues in EC1-IN does not change significantly upon incubation for 28 days at $4{ }^{\circ} \mathrm{C}$. In contrast, emission spectra of $\mathrm{EC} 1$ at $\mathrm{pH}$ 3.0 and 7.0 and its thermal unfolding at $\mathrm{pH} 7.0$ showed significant changes under the same incubation conditions.

Intrinsic fluorescence emission spectra of EC1-PEG between $305 \mathrm{~nm}$ and $405 \mathrm{~nm}$ after excitation at $295 \mathrm{~nm}$ were compared to the $\mathrm{EC} 1$ spectra at $\mathrm{pH} 3.0,7.0$, and 9.0 (Table 1). The wavelength of maximum emission at $\mathrm{pH} 3.0$ was $339.87 \pm 0.03 \mathrm{~nm}$ for EC1-PEG, similar to that for EC1 $(339.93 \pm 0.04 \mathrm{~nm})$ at $\mathrm{pH} 3.0$. At $\mathrm{pH} 7.0$, it was $339.83 \pm 0.05 \mathrm{~nm}$, similar to that of EC1 $(339.27 \pm 0.03 \mathrm{~nm})$ at $\mathrm{pH} 7.0$. At $\mathrm{pH} 9.0$, however, there was a small but significant difference in the wavelengths of maximum emission of EC1-PEG (339.97 \pm $0.02 \mathrm{~nm})$ and $\mathrm{EC} 1(341.31 \pm 0.03 \mathrm{~nm})$. A possible explanation for this difference at $\mathrm{pH} 9.0$ is that the PEG interacts with at least one of the two Trp residues, probably the Trp6 residue that is near the site of PEGylation at the Cys 13 residue. The presence of the bulky PEG group near the Cys13 residue makes Trp6 less exposed to the solvent in EC1-PEG than in EC1.

\section{DISCUSSION}

Our long-term goal is to understand the in vitro and in vivo biological functions of the EC1 domain in inhibiting homotypic and heterotypic cell-cell adhesion. Because of the instability of EC1, it is necessary to find a method for stabilizing it for its long-term use in biological assays. One way to prevent the aggregation/precipitation of $\mathrm{EC} 1$ is by inhibiting the covalent dimerization of EC1 via the Cys13 residue (Makagiansar et al., 2002b). The X-ray structure of EC1 shows that the Cys13 residue is exposed on the surface of EC1 (Nagar et al., 1996); it is adjacent to Trp6, which can cause domain swapping between two EC1 molecules to form a physical dimer (Pokutta et al., 2008). Molecular modeling studies indicate that the formation of a covalent dimer of EC1 (EC1-ss-EC1) is a facile reaction (Makagiansar et al., 2002b). We have shown that the formation of EC1-ss-EC1 dimer increases the dynamic properties of the EC1 unit compared to the EC1 monomer (Trivedi et al., 2009). The dynamic nature of EC1-ss-EC1 may contribute to its susceptibility to peptide bond hydrolysis and aggregation reactions. Thus, alkylation of the Cys 13 residue could prevent intermolecular disulfide bond formation that leads to aggregation of EC1.

Here, we have demonstrated that the thiol group of Cys 13 can be modified to a thioether by alkylation reaction with iodoacetate, iodoacetamide, and maleimide-PEG to generate EC1IA, EC-IN, and EC1-PEG, respectively. The PEG group was conjugated via nucleophilic attack of the maleimide group by the thiol of the Cys 13 residue on EC1 to produce EC1PEG. This reaction produced the PEGylated product with a single site of modification as determined by HPLC and mass spectrometry. Although the Cys 13 residue is exposed on the surface of EC1, the alkylation reaction of the thiol group of the folded form of EC1 was slow; the reaction was accelerated by partially unfolding the protein by incubation in $4.0 \mathrm{M}$ $\mathrm{Gdn} . \mathrm{HCl}$ solution. Gradient removal of $\mathrm{Gdn} . \mathrm{HCl}$ refolded the EC1-IN and EC1-PEG properly to provide a structure similar to that of the parent $\mathrm{EC} 1$ protein as determined by CD. Unfortunately, while EC1-IA was successfully synthesized, it did not refold properly. 
Therefore, EC1-IA was not investigated further for stability studies. The additional negative charge on the acetate group of EC1-IA may prevent its proper refolding due to destabilization of the refolding intermediate via repulsion of negative charges or stabilizing the undesirable intermediate via charge-charge interactions (i.e. salt bridge). A similar result has been observed in the derivatization of sorghum phosphoenolpyruvate carboxylase (PEPC) mutant with iodoacetate; the derivatized product has decreased enzymatic activity (Duff et al., 1993). In contrast, its derivatization with iodoacetamide did not change the enzymatic activity of the enzyme (Duff et al., 1993). This result suggests that this difference in enzymatic activity can be attributed to the introduction of a negative charge in PEPC upon iodoacetate derivatization but no additional negative charge when derivatized with iodoacetamide.

Although EC-IN has a CD spectrum similar to that of EC1 at pH 7.0, the CD spectra of EC1-IN are sensitive to $\mathrm{pH}$ changes. At $\mathrm{pH}$ 7.0, the EC1-IN has estimated secondary structure content similar to that of EC1 from the CD spectra; EC1-IN has $47 \% \beta$-sheet, $5 \%$ a-helix, and $48 \%$ random coil and EC1 has $51 \% \beta$-sheet, $2 \%$ a-helix, and $47 \%$ random coil. On the other hand, the CD spectra of EC1-IN were dramatically different from those of the EC1 protein at $\mathrm{pH} 3.0$ and 9.0. The sensitivity of EC1-IN to $\mathrm{pH}$ changes could be due to the different electronic properties and hydrogen bonding potential of the amide group of derivatized Cys13 on EC1-IN compared to the parent thiol group of Cys13 on the EC1 protein. The thiol group of Cys13 in EC1 can be ionized to thiolate ion (pKa around 9.1) and it can form electrostatic interactions with surrounding functional groups. In contrast, the amide group of the derivatized Cys13 cannot be ionized and may not form efficient interactions with surrounding functional groups. As noted previously, the thiol group of Cys 13 was not very reactive in the folded form of EC1 and this thiol group could only be derivatized in the unfolded form. This observation suggests that the thiol group of Cys13 is involved in hydrogen bonding and/or electrostatic interactions with surrounding functional groups to stabilize EC1 tertiary structure. Altered secondary structures of proteins upon derivatization have been observed previously in thiol-alkylated ovalbumin using iodoacetate and iodoacetamide. The alkylated ovalbumin and BSA have a decreased $a$-helical content and an increased $\beta$-sheet content (Batra et al., 1989a, b).

The stability of EC1-IN and EC1 monitored by CD and fluorescence indicates that EC1-IN is more stable than $\mathrm{EC} 1$ under $\mathrm{pH} 3.0$ and $4{ }^{\circ} \mathrm{C}$ for 14 days. The fluorescence emission spectra of EC1-IN did not change upon incubation for 28 days at $4{ }^{\circ} \mathrm{C}$, but there was a blue shift in the emission spectra of EC1 upon treatment under the same condition. The melting temperatures $\left(\mathrm{T}_{\mathrm{m}}\right)$ of EC1-IN estimated from $\mathrm{CD}$ spectra at both $\mathrm{pH} 3.0$ and 9.0 are higher than the $\mathrm{T}_{\mathrm{m}}$ of EC1. For example, the $\mathrm{T}_{\mathrm{m}}$ of EC1-IN is $39.9 \pm 1.0^{\circ} \mathrm{C}$, whereas the $\mathrm{T}_{\mathrm{m}}$ of $\mathrm{EC} 1$ is $28.8 \pm 0.3{ }^{\circ} \mathrm{C}$ at $\mathrm{pH} 3.0$. At $\mathrm{pH} 7.0$, however, the $\mathrm{T}_{\mathrm{m}}$ of EC1-IN $\left(33.9 \pm 0.7^{\circ} \mathrm{C}\right)$ is lower than the $\mathrm{T}_{\mathrm{m}}$ of EC1 $\left(42.0 \pm 0.6^{\circ} \mathrm{C}\right)$. A decrease in thermal stability has been reported previously upon Cys residue alkylation of alpha-alpha tropomyosin (AAT) (Holtzer et al., 1990). It is interesting to find that although EC1-IN has a lower $T_{m}$ than $E C 1$ at $p H ~ 7.0$, incubation of EC1-IN at $4{ }^{\circ} \mathrm{C}$ for 28 days did not result in any change in CD spectra. This is in contrast to incubation of $\mathrm{EC} 1$ under the same conditions, which produced different $\mathrm{CD}$ spectra due to aggregation (Trivedi et al., 2009). These results also support the idea that the presence of the free thiol group in EC1 catalyzed its instability by forming a covalent dimer, and the prevention of covalent dimerization inhibited the formation of protein aggregates and precipitates. Therefore, the $\mathrm{T}_{\mathrm{m}}$ alone may not be sufficient for determining the instability of a protein.

Because EC1-IN has different conformations than the parent EC1 at pH 3.0 and 9.0 and also has a lower $\mathrm{T}_{\mathrm{m}}$ than the parent $\mathrm{EC} 1$ at $\mathrm{pH} 7.0$, an alternative alkylation method such as PEGylation was utilized to improve the stability of EC1 (Morar et al., 2006). In this case, 
the thiol group of the Cys13 residue was reacted with maleimide polyethylene glycol (PEG) to make EC1-PEG, and its structural characteristics were evaluated using spectroscopic methods. PEGylation of the Cys residues of proteins has been employed previously to improve protein in vitro and in vivo stabilities (Bell et al., 2008; Colonna et al., 2008; Long et al., 2006; Rosendahl et al., 2005a; Rosendahl et al., 2005b; Tsutsumi et al., 2000; Vanwetswinkel et al., 2000). PEGylation also does not change the protein secondary structure compared to that of the parent protein (Digilio et al., 2003; Hinds and Kim, 2002). Far UV CD studies showed some minor differences between CD spectra of EC1-PEG and $\mathrm{EC} 1$ at $\mathrm{pH}$ 3.0. At $\mathrm{pH} 7.0$ and 9.0, however, no substantial differences were observed between the CD spectra of EC1-PEG and EC1. Compared to EC1-IN, the secondary structure of EC1-PEG is less sensitive to $\mathrm{pH}$ changes. The thermal unfolding profiles determined by $\mathrm{CD}$ spectroscopy suggest that $\mathrm{EC} 1-\mathrm{PEG}$ is significantly more stable than $\mathrm{EC} 1$; the increases in $\mathrm{T}_{\mathrm{m}}$ of EC1-PEG compared to $\mathrm{EC} 1$ are $5.1{ }^{\circ} \mathrm{C}$ at $\mathrm{pH} 3.0,4.0^{\circ} \mathrm{C}$ at $\mathrm{pH}$ 7.0, and $7.7^{\circ} \mathrm{C}$ at $\mathrm{pH} 9.0$ (Fig. 8). A similar trend was observed by plotting the change in fluorescence wavelength maximum as a function of temperature. The EC1-PEG protein was more stable than EC1-IN or EC1 after incubation for $4 \mathrm{~h}$ at $70{ }^{\circ} \mathrm{C}$ at all three different $\mathrm{pH}$ values (3.0, 7.0. and 9.0). EC1-IN was more stable than $\mathrm{EC} 1$ at $\mathrm{pH} 7.0$ and 9.0, but both proteins were equally unstable at $\mathrm{pH} 3.0$. As with $\mathrm{EC} 1$ at $\mathrm{pH} 3.0$ and $70{ }^{\circ} \mathrm{C}, \mathrm{EC} 1-\mathrm{IN}$ was chemically degraded via peptide bond hydrolysis at Asp93-Pro94, and only 22\% of EC1-IN remained in solution after 4-h incubation. Only $10 \%$ of the hydrolysis product was observed in solution because the degradation involved precipitation of the protein. All the methods examined so far indicate that PEGylation is the best strategy for stabilizing the EC1 protein. It is also possible that the PEGylation of EC1 decreases the dynamic properties of EC1PEG, which contributes to the decrease in the hydrolysis reaction; however, this proposal needs further investigation.

PEGylation of therapeutic proteins has been shown to improve their physical and biological properties. PEGylated proteins have a larger hydrodynamic radius with lower glomerular filtration, lower immunogenicity, and a higher enzymatic stability compared to the parent protein. It was proposed that PEGylation at several sites on a protein with higher molecular weight branched PEGs as opposed to linear PEG can form a polymer shell around the protein; this recruits water to form an outer water shell that minimizes intermolecular protein interactions (Long et al., 2006; Morar et al., 2006; Rosendahl et al., 2005a; Rosendahl et al., 2005b; Tsutsumi et al., 2000; Vanwetswinkel et al., 2000). Thus, PEGylation of therapeutic proteins produces a higher protein systemic circulation, and the amount and frequency of dosing can be reduced. In EC1-PEG, the PEG group may not be large enough to form a shell around the entire EC1 molecule because it is a linear 5,000 Da PEG. The X-ray structure of EC1 shows that the Trp6 and Cys 13 residues are located at the dimerization surface. The Xray structure of EC1 of C-cadherin shows that the equivalent Trp residue is involved in domain swapping between two EC1 domains. In other words, the Trp residue on one EC1 is buried in a hydrophobic pocket of another EC1 to form a physical dimer (Boggon et al., 2002). It has been suggested that EC1 could have two homophilic binding surfaces, one at the domain-swapping region at the N-terminal and the other in the region where the HisAla-Val (HAV) and Ala-Asp-Thr (ADT) sequences are located (Makagiansar et al., 2001; Sinaga et al., 2002). Thus, we propose that the presence of the PEG on EC1-PEG near the domain-swapping region may prevent the formation of physical and chemical dimers of EC1 of E-cadherin. However, the presence of PEG group Cys-13 may not interfere with HAV region of EC1-PEG for binding to E-cadherin molecules on the cell surface to block cell-cell adhesion. In addition, EC1-PEG can be used to elucidate the role of the surface opposite to the PEGylation surface (HAV and ADT surface) on E-cadherin in mediating homophilic and heterophilic cell-cell adhesion (Kiptoo et al., 2011; Kobayashi et al., 2006; Makagiansar et al., 2001; Sinaga et al., 2002). It is not yet clear whether the size of PEG molecules can influence the stability and bioactivity of the EC1-PEG protein. However, the increase in size 
of PEG molecules can increase the vivo systemic circulation of PEGylated protein; this is presumably due to the increase of the hydrodynamic radius of the PEGylated protein.

In conclusion, alkylation of the Cys residue in EC1 improves the stability of the EC1 domain, indicating that the formation of a covalent dimer of $\mathrm{EC} 1$ is crucial for the instability of EC1. The EC1-PEG is the best modification for improving chemical and physical stability and long-term storage of EC1. Unlike the modified EC1-IN protein, EC1-PEG has a structure similar to that of the parent $\mathrm{EC} 1$ at different $\mathrm{pH}$ values. In the future, the biological activity of EC1-PEG will be compared to that of EC1-IN and EC1 in inhibiting E-cadherinmediated homotypic and heterotypic cell-cell adhesion in in vitro cell culture systems developed in our laboratory (Kobayashi et al., 2006).

\section{Acknowledgments}

This work was supported by a grant from the National Institutes of Health (R01-NS-075374). We also thank Nancy Harmony for proofreading this manuscript.

\section{References}

Batra PP, Sasa K, Ueki T, Takeda K. Circular dichroic study of conformational changes in ovalbumin induced by modification of sulfhydryl groups and disulfide reduction. J Protein Chem. 1989a; 8:609-6117. [PubMed: 2610856]

Batra PP, Sasa K, Ueki T, Takeda K. Circular dichroic study of the conformational stability of sulfhydryl-blocked bovine serum albumin. Int J Biochem. 1989b; 21:857-862. [PubMed: 2583353]

Bell SJ, Fam CM, Chlipala EA, Carlson SJ, Lee JI, Rosendahl MS, Doherty DH, Cox GN. Enhanced circulating half-life and antitumor activity of a site-specific pegylated interferon-alpha protein therapeutic. Bioconjug Chem. 2008; 19:299-305. [PubMed: 18020402]

Boggon TJ, Murray J, Chappuis-Flament S, Wong E, Gumbiner BM, Shapiro L. C-cadherin ectodomain structure and implications for cell adhesion mechanisms. Science. 2002; 296:13081313. [PubMed: 11964443]

Colonna C, Conti B, Perugini P, Pavanetto F, Modena T, Dorati R, Iadarola P, Genta I. Site-directed PEGylation as successful approach to improve the enzyme replacement in the case of prolidase. Int J Pharm. 2008; 358:230-237. [PubMed: 18455892]

Derrick TS, Kashi RS, Durrani M, Jhingan A, Middaugh CR. Effect of metal cations on the conformation and inactivation of recombinant human factor VIII. J Pharm Sci. 2004; 93:2549_ 2557. [PubMed: 15349964]

Dickens F. Interaction of halogenacetates and SH compounds: The reaction of halogenacetic acids with glutathione and cysteine. The mechanism of iodoacetate poisoning of glyoxalase. Biochem J. 1933; 27:1141-1151. [PubMed: 16745202]

Digilio G, Barbero L, Bracco C, Corpillo D, Esposito P, Piquet G, Traversa S, Aime S. NMR Structure of two novel polyethylene glycol conjugates of the human growth hormone-releasing factor, hGRF(1-29)-NH 2 . J Am Chem Soc. 2003; 125:3458-3470. [PubMed: 12643708]

Duff SM, Duff SM, Lepiniec L, Crétin C, Andreo CS, Condon SA, Sarath G, Vidal J, Gadal P, Chollet $R$. An engineered change in the L-malate sensitivity of a site-directed mutant of sorghum phosphoenolpyruvate carboxylase: the effect of sequential mutagenesis and S-carboxymethylation at position 8. Arch Biochem Biphys. 1993; 306:272-276.

Hinds KD, Kim SW. Effects of PEG conjugation on insulin properties. Adv Drug Del Rev. 2002; 54:505-530.

Holtzer ME, Holtzer A, Crimmins DL. The effect of sulfhydryl blocking groups on the thermal unfolding of alpha alpha tropomyosin coiled coils. Biochem Biophys Res Commun. 1990; 166:1279-83. [PubMed: 2306243]

Kiptoo P, Sinaga E, Calcagno AM, Zhao H, Kobayashi N, Tambunan US, Siahaan TJ. Enhancement of drug absorption through the blood-brain barrier and inhibition of intercellular tight junction 
resealing by E-cadherin peptides. Molecular pharmaceutics. 2011; 8:239-249. [PubMed: 21128658]

Kobayashi N, Ikesue A, Majumdar S, Siahaan TJ. Inhibition of E-cadherin-mediated homotypic adhesion of Caco-2 cells: a novel evaluation assay for peptide activities in modulating cell-cell adhesion. J Pharmacol Exp Ther. 2006; 317:309-316. [PubMed: 16371447]

Long DL, Doherty DH, Eisenberg SP, Smith DJ, Rosendahl MS, Christensen KR, Edwards DP, Chlipala EA, Cox GN. Design of homogeneous, monopegylated erythropoietin analogs with preserved in vitro bioactivity. Exp Hematol. 2006; 34:697-704. [PubMed: 16728273]

Makagiansar I, Avery M, Hu Y, Audus KL, Siahaan TJ. Improving the selectivity of HAV-peptides in modulating E-cadherin-E-cadherin interactions in the intercellular junction of MDCK cell monolayers. Pharm Res. 2001; 18:446-553. [PubMed: 11451030]

Makagiansar IT, Ikesue A, Duc Nguyen P, Urbauer JL, Bieber Urbauer RJ, Siahaan TJ. Localized production of human E-cadherin-derived first repeat in Escherichia coli. Protein Expression and Purification. 2002a; 26:449-454. [PubMed: 12460769]

Makagiansar IT, Nguyen PD, Ikesue A, Kuczera K, Dentler W, Urbauer JL, Galeva N, Alterman M, Siahaan TJ. Disulfide bond formation promotes the cis- and trans-dimerization of the E-cadherinderived first repeat. J Biol Chem. 2002b; 277:16002-16010. [PubMed: 11856755]

Morar, AS.; Schrimsher, JL.; Chavez, MD. PEGylation of proteins: A structural approach. BioPharm. 2006.

http://biopharminternational.findpharma.com/biopharm/Article/PEGylation-of-Proteins-AStructural-Approach/ArticleStandard/Article/detail/317577

Nagar B, Overduin M, Ikura M, Rini JM. Structural basis of calcium-induced E-cadherin rigidification and dimerization. Nature. 1996; 380:360-364. [PubMed: 8598933]

Pokutta S, Drees F, Yamada S, Nelson WJ, Weis WI. Biochemical and structural analysis of alphacatenin in cell-cell contacts. Biochem Soc Trans. 2008:141-147. [PubMed: 18363554]

Pokutta S, Weis WI. Structure and mechanism of cadherins and catenins in cell-cell contacts. Annu Rev Cell Dev Biol. 2007; 23:237-261. [PubMed: 17539752]

Rexroad J, Wiethoff CM, Green AP, Kierstead TD, Scott MO, Middaugh CR. Structural stability of adenovirus type 5. J Pharm Sci. 2003; 92:665-678. [PubMed: 12587128]

Rosendahl MS, Doherty DH, Smith DJ, Bendale AM, Cox GN. Site specific protein PEGylation: Application to Cysteine Analogs of Recombinant Human Granulocyte Colony-Stimulating factor. Bioprocess Inter. 2005a; 3:52-62.

Rosendahl MS, Doherty DH, Smith DJ, Carlson SJ, Chlipala EA, Cox GN. A long acting, highly potent interferon a-2 conjugate created using site-specific PEGylation. Bioconj Chem. 2005b; 16:200-207.

Shiraishi K, Tsuzaka K, Yoshimoto K, Kumazawa C, Nozaki K, Abe T, Tsubota K, Takeuchi T. Critical role of the fifth domain of E-cadherin for heterophilic adhesion with alpha $\mathrm{E}$ beta 7, but not for homophilic adhesion. J Immunol. 2005; 175:1014-1021. [PubMed: 16002701]

Sinaga E, Jois SD, Avery M, Makagiansar IT, Tambunan US, Audus KL, Siahaan TJ. Increasing paracellular porosity by E-cadherin peptides: Discovery of bulge and groove regions in the EC1domain of E-cadherin. Pharm Res. 2002; 19:1170-1179. [PubMed: 12240943]

Smythe CV. The reaction of iodoacetate and iodoacetamide on various sulfydyl groups, with urease, and with yest preparations. J Biol Chem. 1936; 114:601-612.

Trivedi M, Davis RA, Shabaik Y, Roy A, Verkhivker G, Laurence JS, Middaugh CR, Siahaan TJ. The role of covalent dimerization on the physical and chemical stability of the EC1 domain of human E-cadherin. Journal of pharmaceutical sciences. 2009; 98:3562-3574. [PubMed: 19199298]

Tsutsumi Y, Onda M, Nagata S, Lee B, Kreitman RJ, Pastan I. Site-specific chemical modification withvpolyethylene glycol of rcombinant immuntoxin anti-Tac(Fv)-PE38 (LMB-2) improves antitumor activity and reduces animal toxicity and immunogenicity. Proc Natl Acad Sci U S A. 2000; 97:8548-8553. [PubMed: 10890891]

Vanwetswinkel S, Plaisance S, Zhi-yong Z, Vanlinthout I, Brepoels K, Ladters I, Collen D, Jespers L. Pharmacokinetic and thrombolytic properties of cysteine-linked polyethylene glycol derivatives of staphylokinase. Blood. 2000; 95:936-942. [PubMed: 10648406] 
Zheng K, Laurence JS, Kuczera K, Verkhivker G, Middaugh CR, Siahaan TJ. Characterization of multiple stable conformers of the EC5 domain of E-cadherin and the interaction of EC5 with Ecadherin peptides. Chemical biology \& drug design. 2009a; 73:584-598. [PubMed: 19635050]

Zheng K, Middaugh CR, Siahaan TJ. Evaluation of the physical stability of the EC5 domain of Ecadherin: effects of $\mathrm{pH}$, temperature, ionic strength, and disulfide bonds. Journal of pharmaceutical sciences. 2009b; 98:63-73. [PubMed: 18428798]

Zheng K, Trivedi M, Siahaan TJ. Structure and function of the intercellular junctions: barrier of paracellular drug delivery. Curr Pharm Des. 2006; 12:2813-2824. [PubMed: 16918412] 

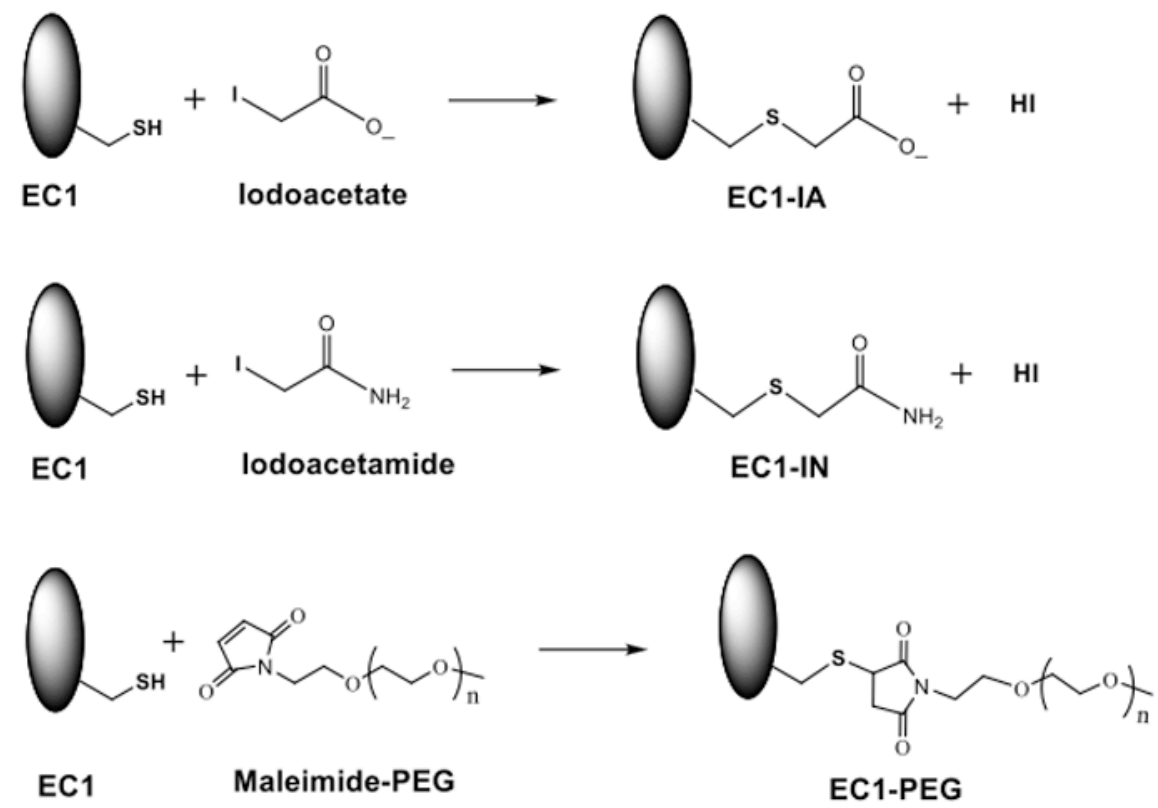

Fig. 1.

The alkylation reaction of the thiol group on the Cys13 residue of EC1 with iodoacetate and iodoacetamide produces the EC1 derivatives EC1-IA and EC1-IN, respectively. The alkylation of the thiol group with maleimide-PEG-5000 generates EC1-PEG molecule. 
Figure 2

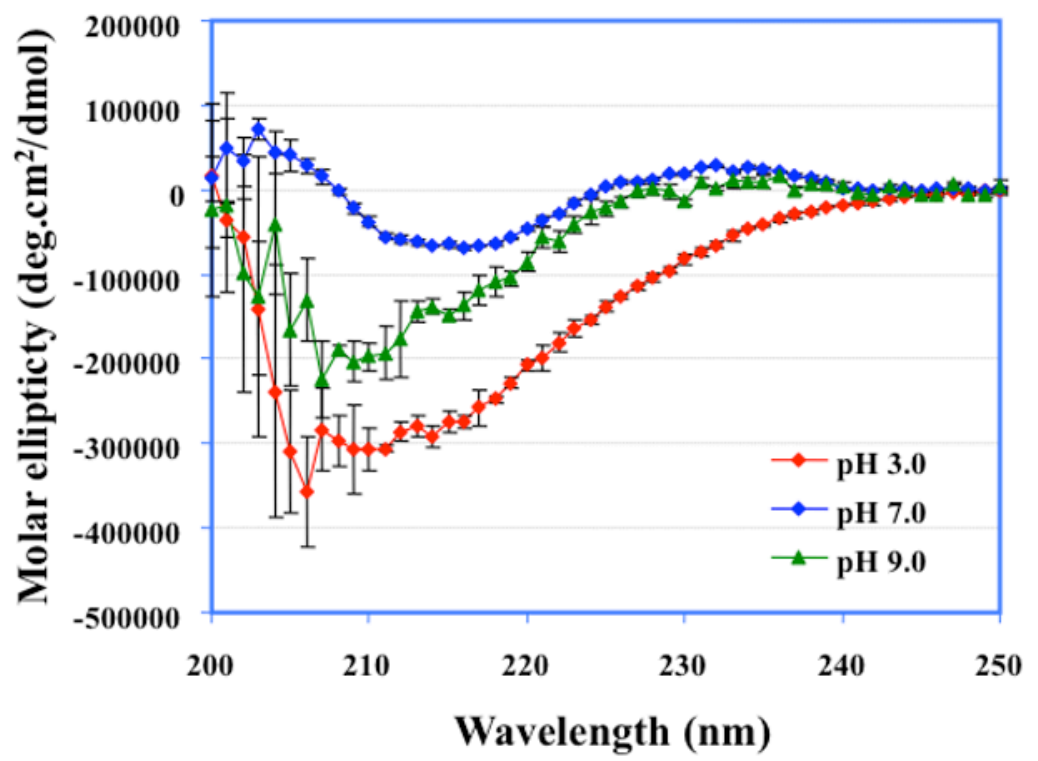

Fig. 2.

The CD spectra of EC1-IN in buffered solutions at $\mathrm{pH}$ 3.0, 7.0, and 9.0. The secondary structure of EC1-IN is affected by the $\mathrm{pH}$ of the solution. 
Figure 3A

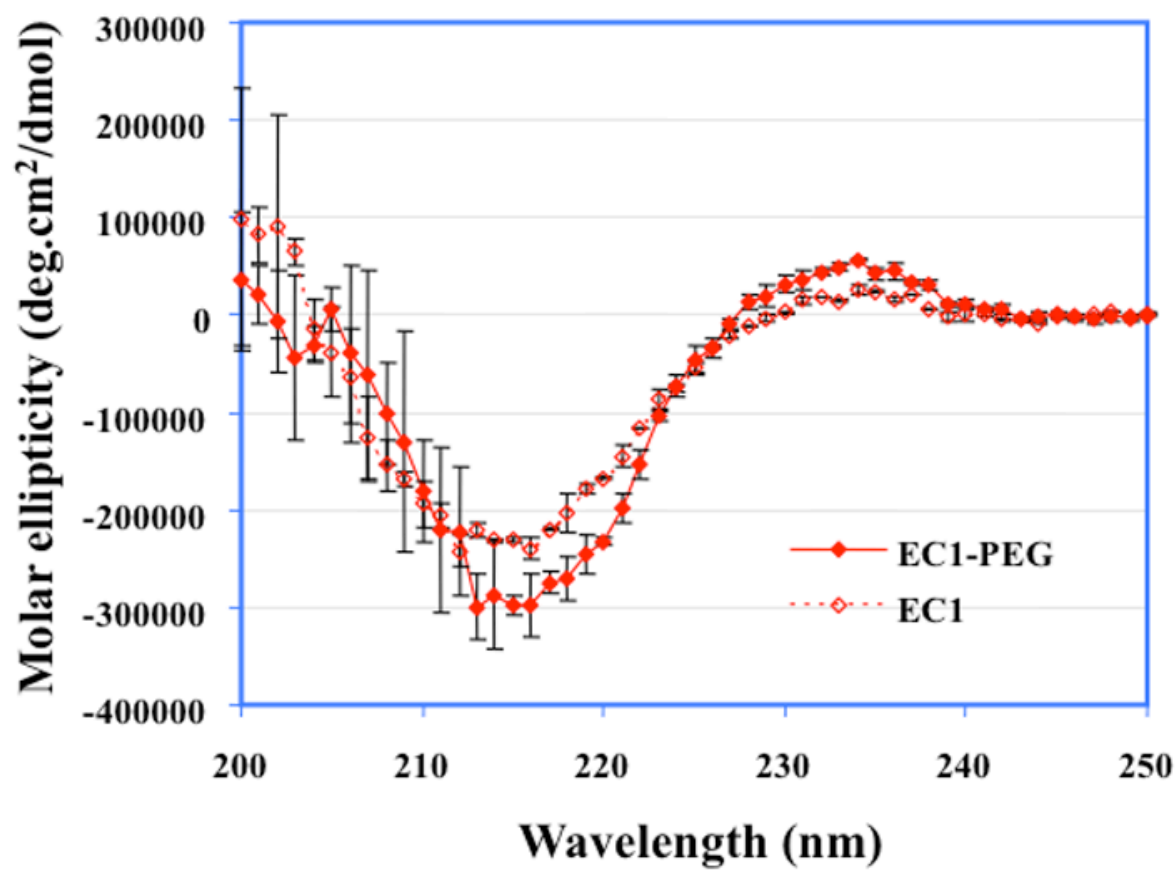

Figure 3B

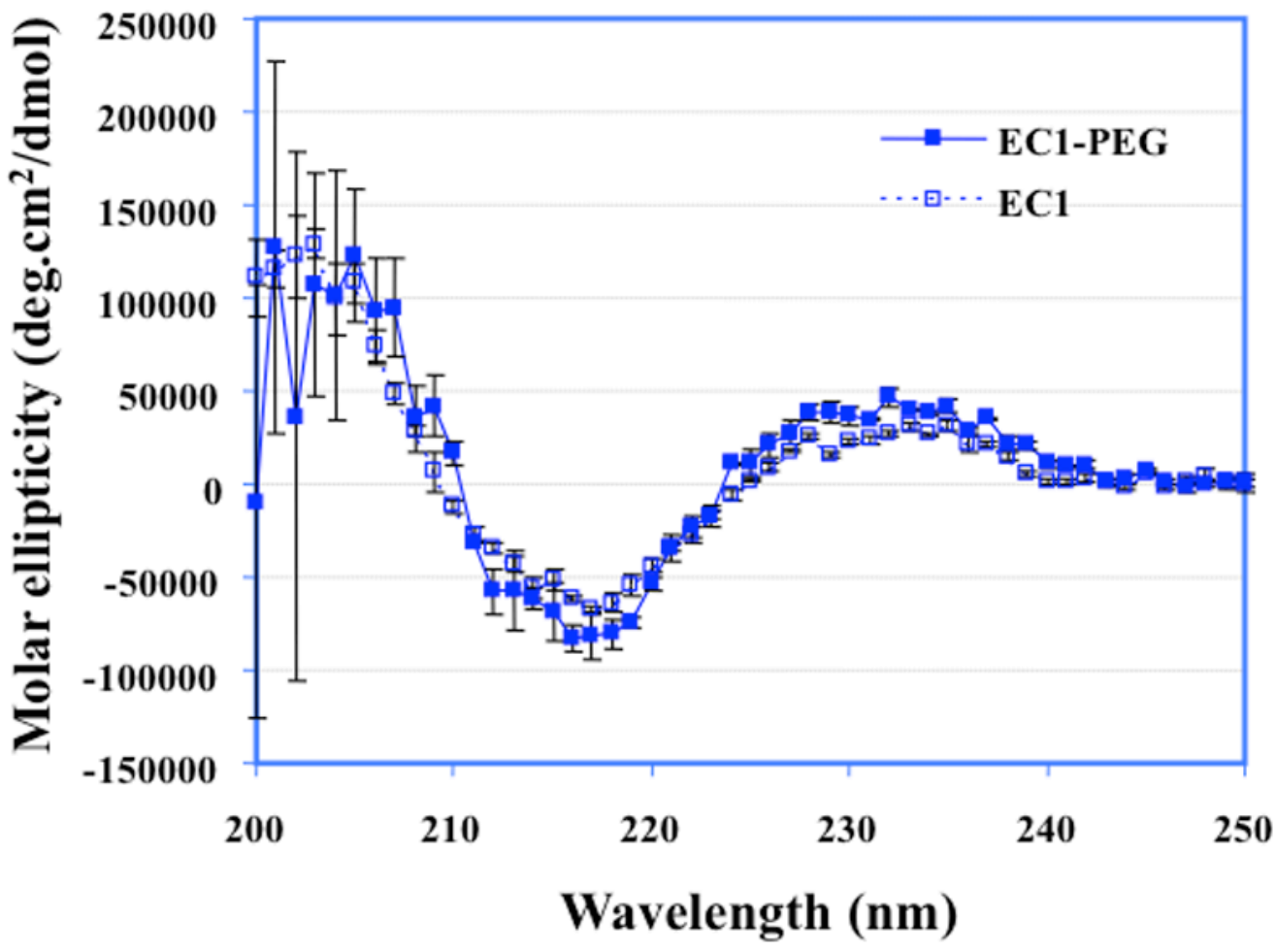

Int J Pharm. Author manuscript; available in PMC 2013 July 15. 
Figure $3 \mathrm{C}$

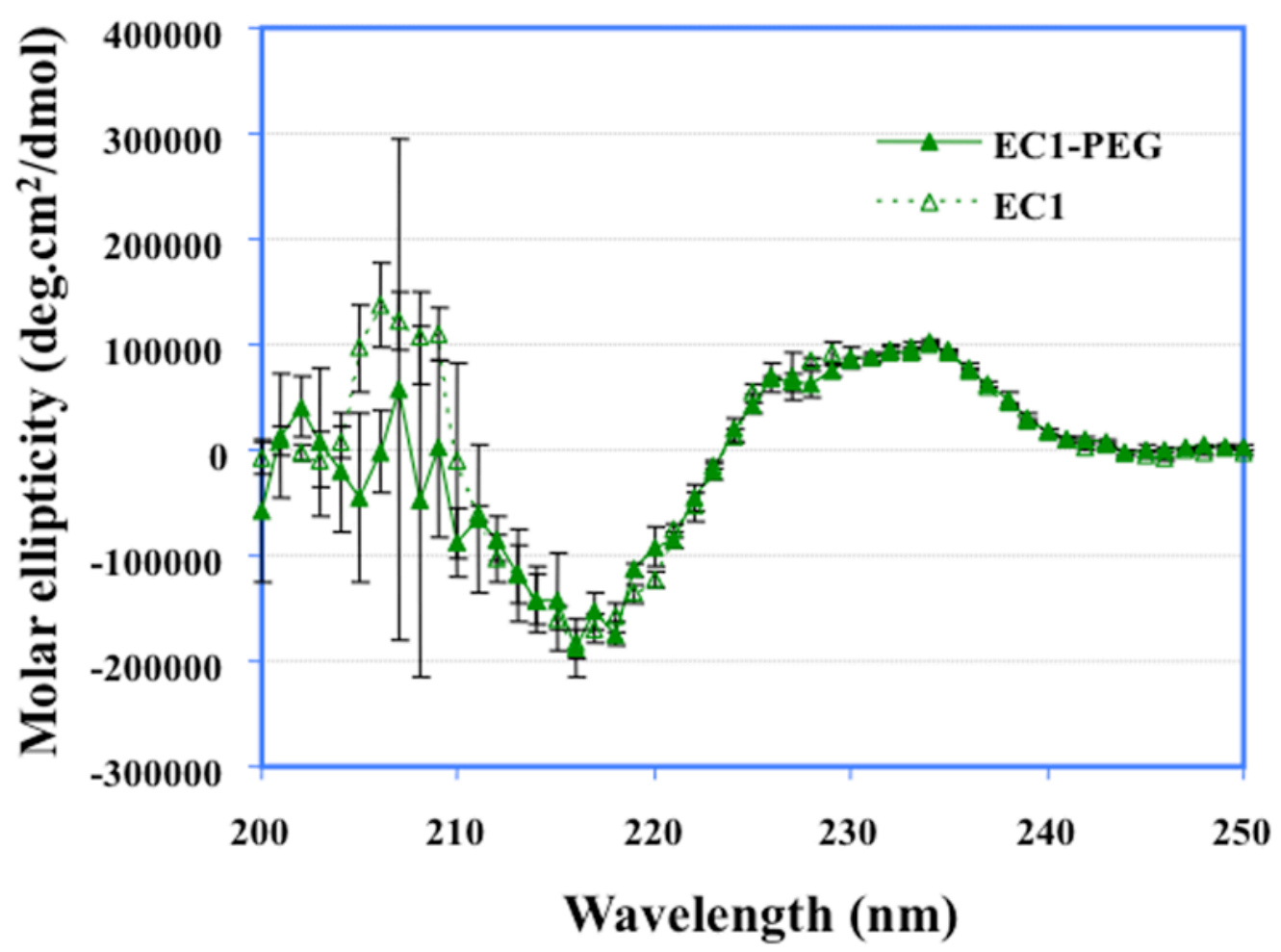

Fig. 3.

Comparisons of the secondary structures of EC1 and EC1-PEG using far UV CD at pH: (A) 3.0, (B) 7.0, and (C) 9.0. The spectrum of EC1-PEG is slightly different than that of EC1 at $\mathrm{pH}$ 3.0. However, the CD spectra of EC1-PEG at $\mathrm{pH} 7.0$ and 9.0 are similar to those from EC1, suggesting that EC1-PEG and EC1 have similar secondary structures at $\mathrm{pH} 7.0$ and 9.0. 


\section{Figure 4A}

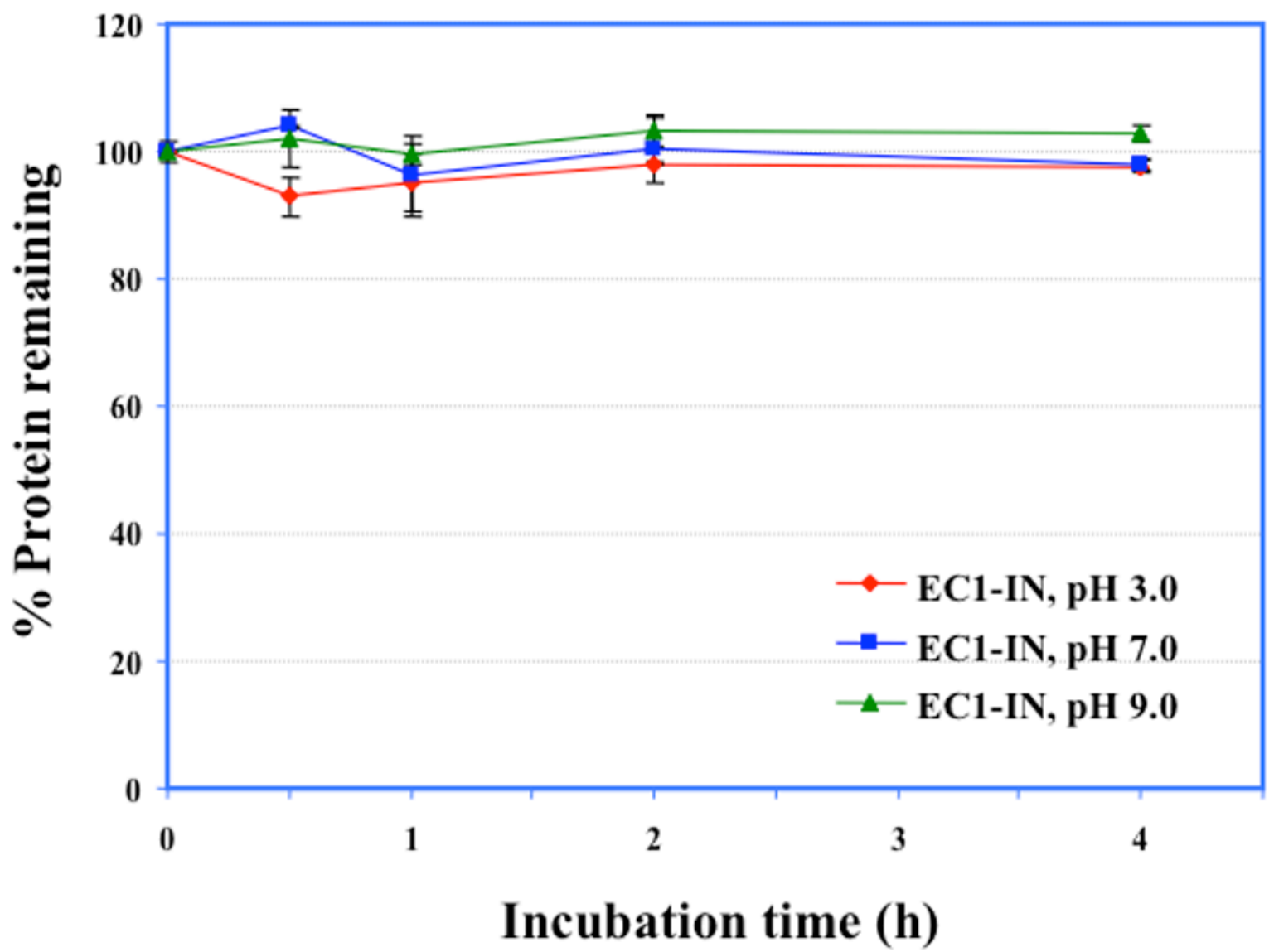

Figure 4B

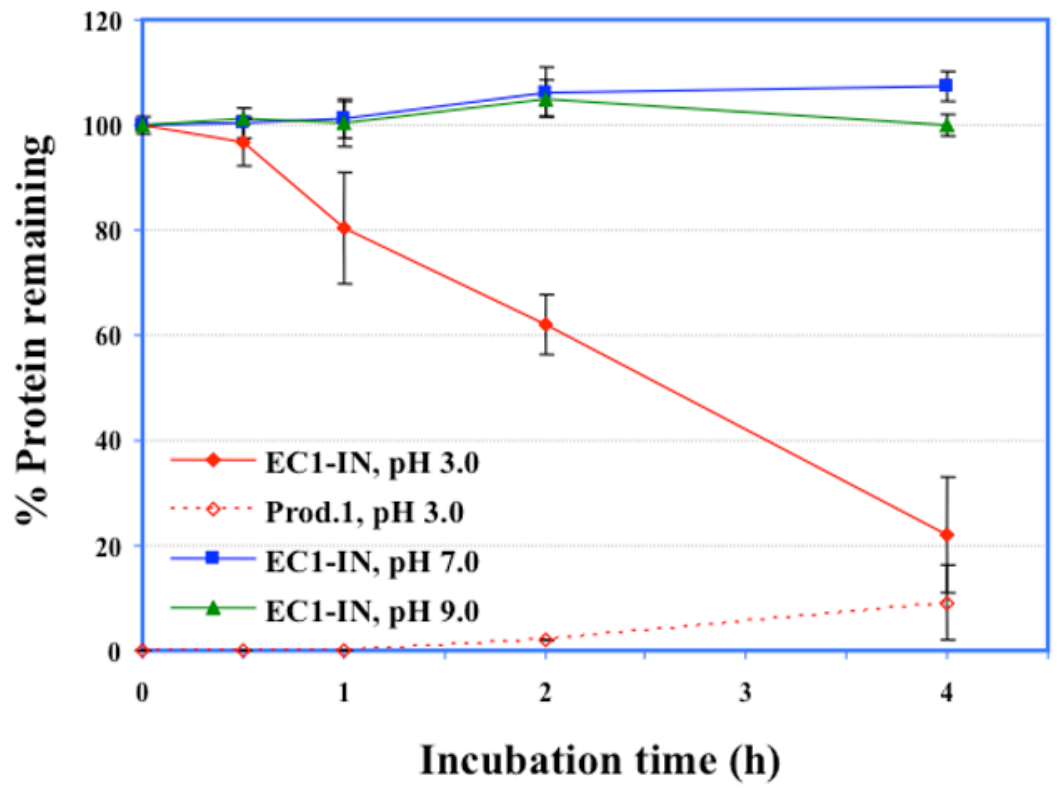

Int J Pharm. Author manuscript; available in PMC 2013 July 15. 
Fig. 4.

The chemical stability profiles of EC1-IN after incubation for $4 \mathrm{~h}$ at $\mathrm{pH} 3.0,7.0$, and 9.0 at: (A) $37{ }^{\circ} \mathrm{C}$ and (B) $70^{\circ} \mathrm{C}$. At $37^{\circ} \mathrm{C}$, EC1-IN does not undergo any chemical degradation or precipitation reaction at $\mathrm{pH} 3.0,7.0$, or 9.0 . At $70{ }^{\circ} \mathrm{C}, \mathrm{EC} 1-\mathrm{IN}$ shows no peptide bond hydrolysis or precipitation at $\mathrm{pH} 7.0$ or 9.0; however, EC1-IN undergoes peptide bond hydrolysis as well as precipitation at $\mathrm{pH}$ 3.0. The product of hydrolysis was identified as the N-terminal fragment G1-D93, a product of hydrolysis at the D93-P94 peptide bond. 


\section{Figure 5}

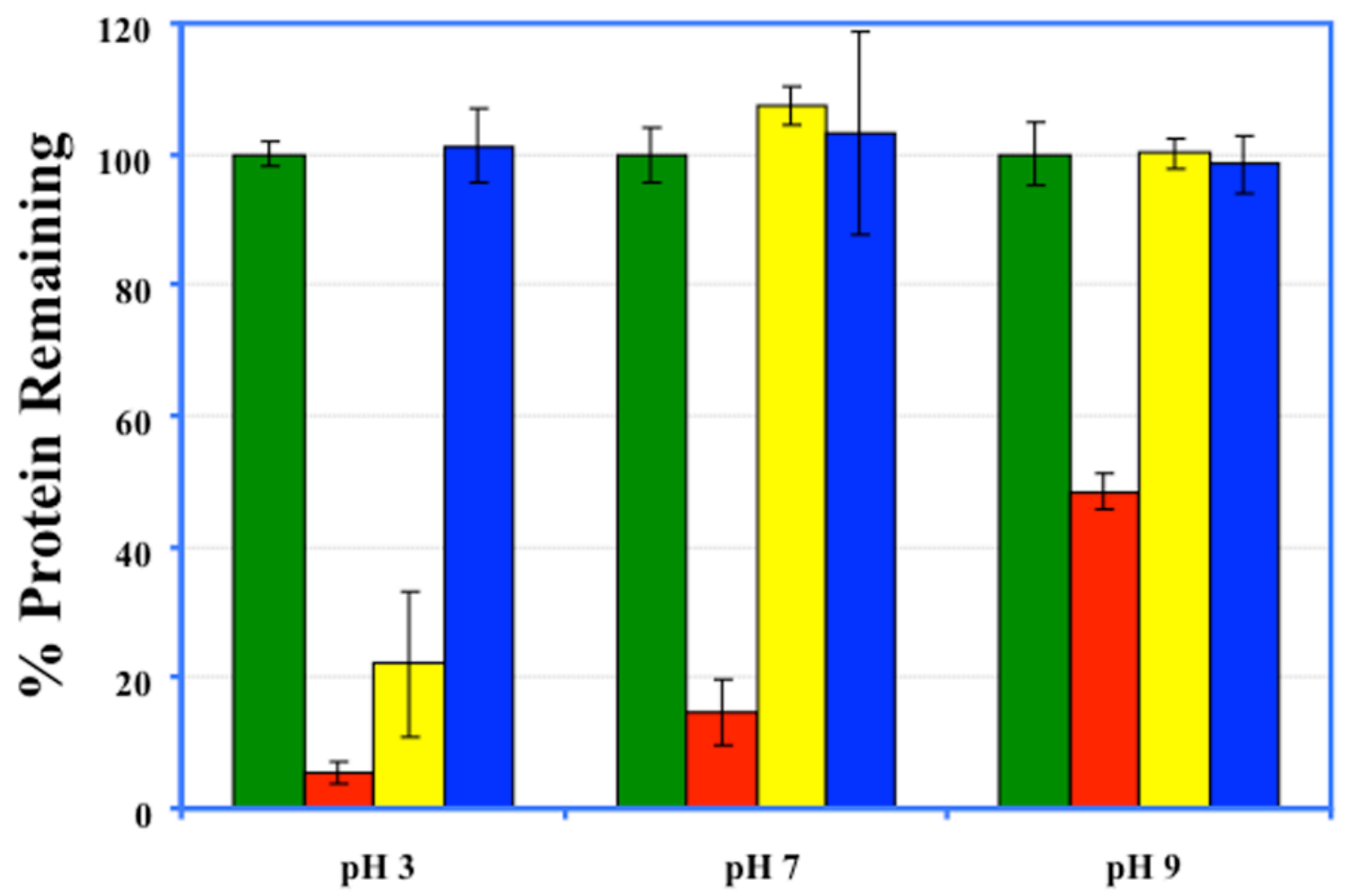

$\square 0 \mathrm{~h} \square \mathrm{EC} 1,4 \mathrm{~h} \quad \square$ EC1-IN, 4h $\square$ EC1-PEG, 4h

Fig. 5.

A comparison of the chemical stability of EC1, EC1-IN, and EC1-PEG at pH 3.0, 7.0, and 9.0 after $4-\mathrm{h}$ incubation at $70{ }^{\circ} \mathrm{C}$. It is clear that EC1-PEG is the most stable molecule at all $\mathrm{pH}$ values. EC-IN is stable at $\mathrm{pH} 7.0$ and 9.0 but not at $\mathrm{pH} 3.0$. EC1 is the least stable molecule at all pH values compared to EC1-PEG and EC1-IN. 
Figure 6A

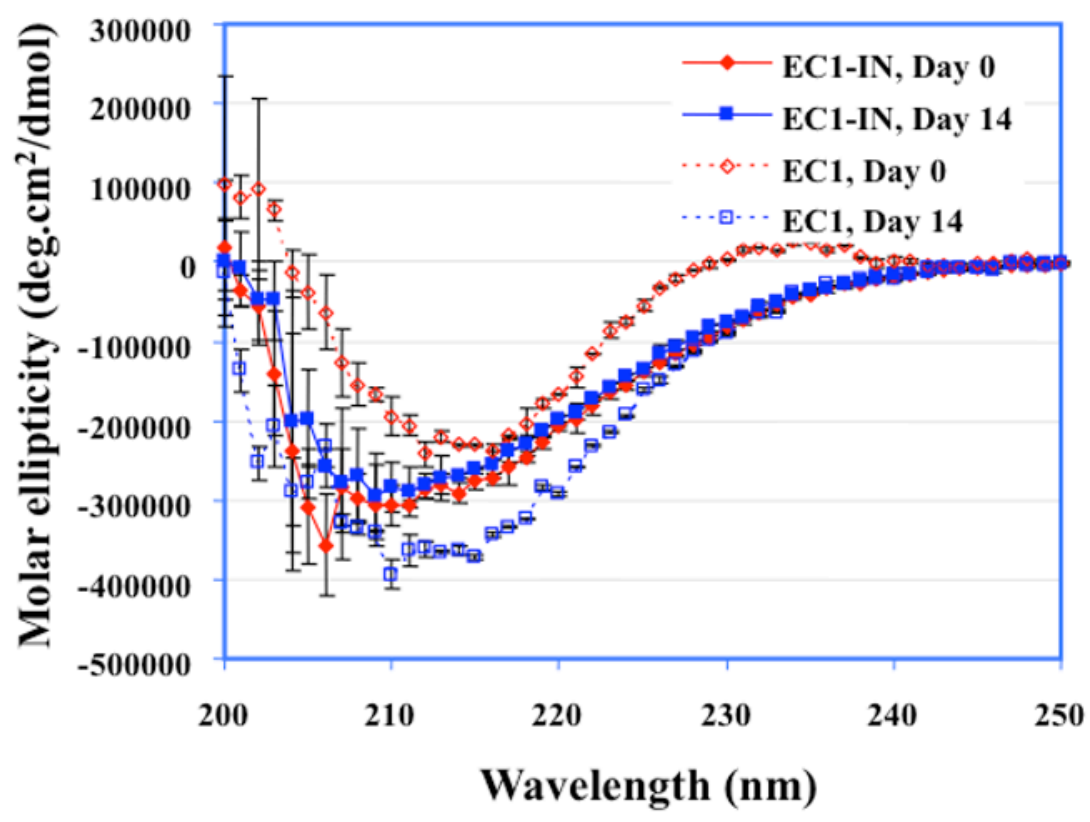

Int J Pharm. Author manuscript; available in PMC 2013 July 15. 
Figure 6B

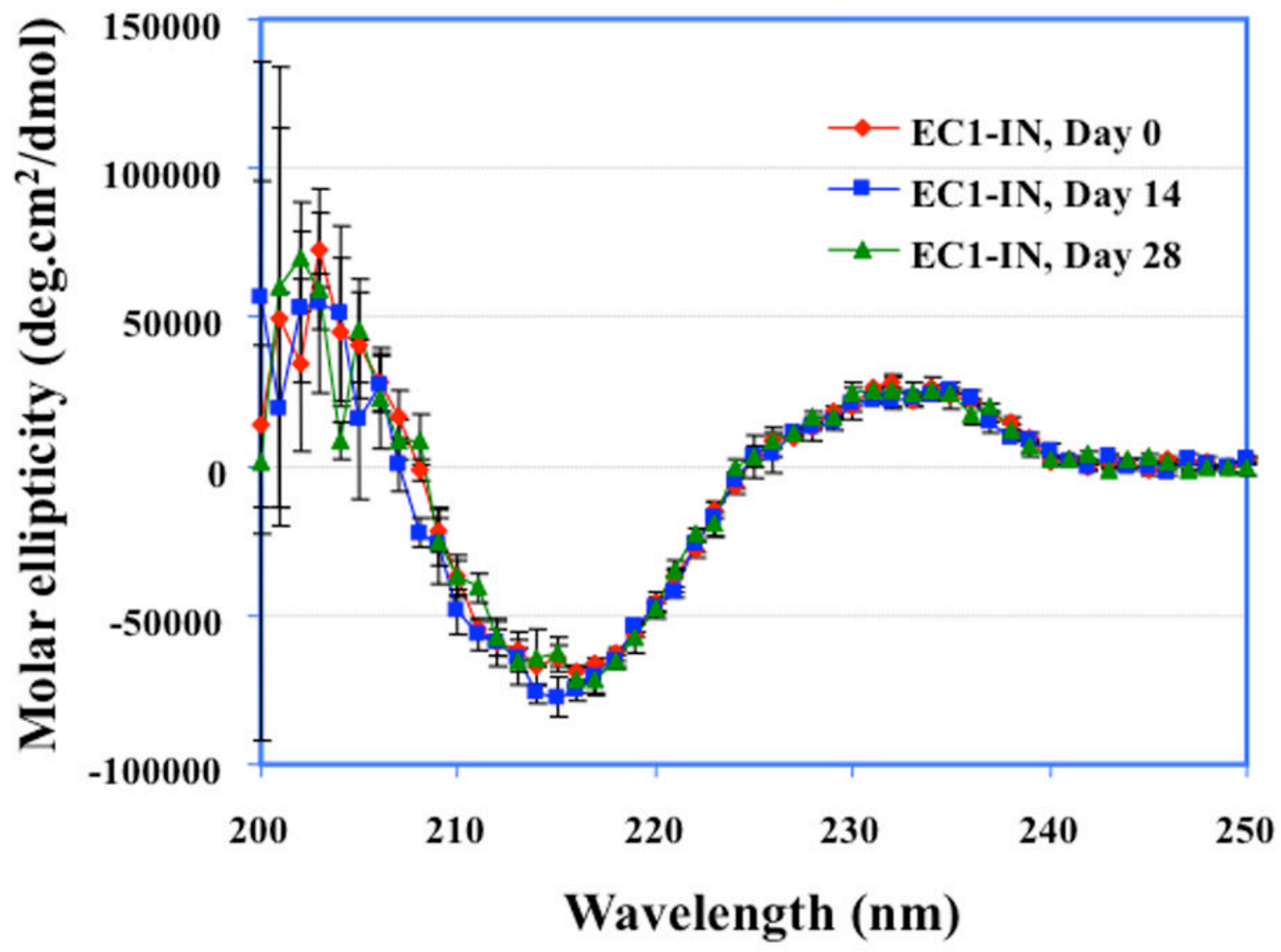




\section{Figure 6C}

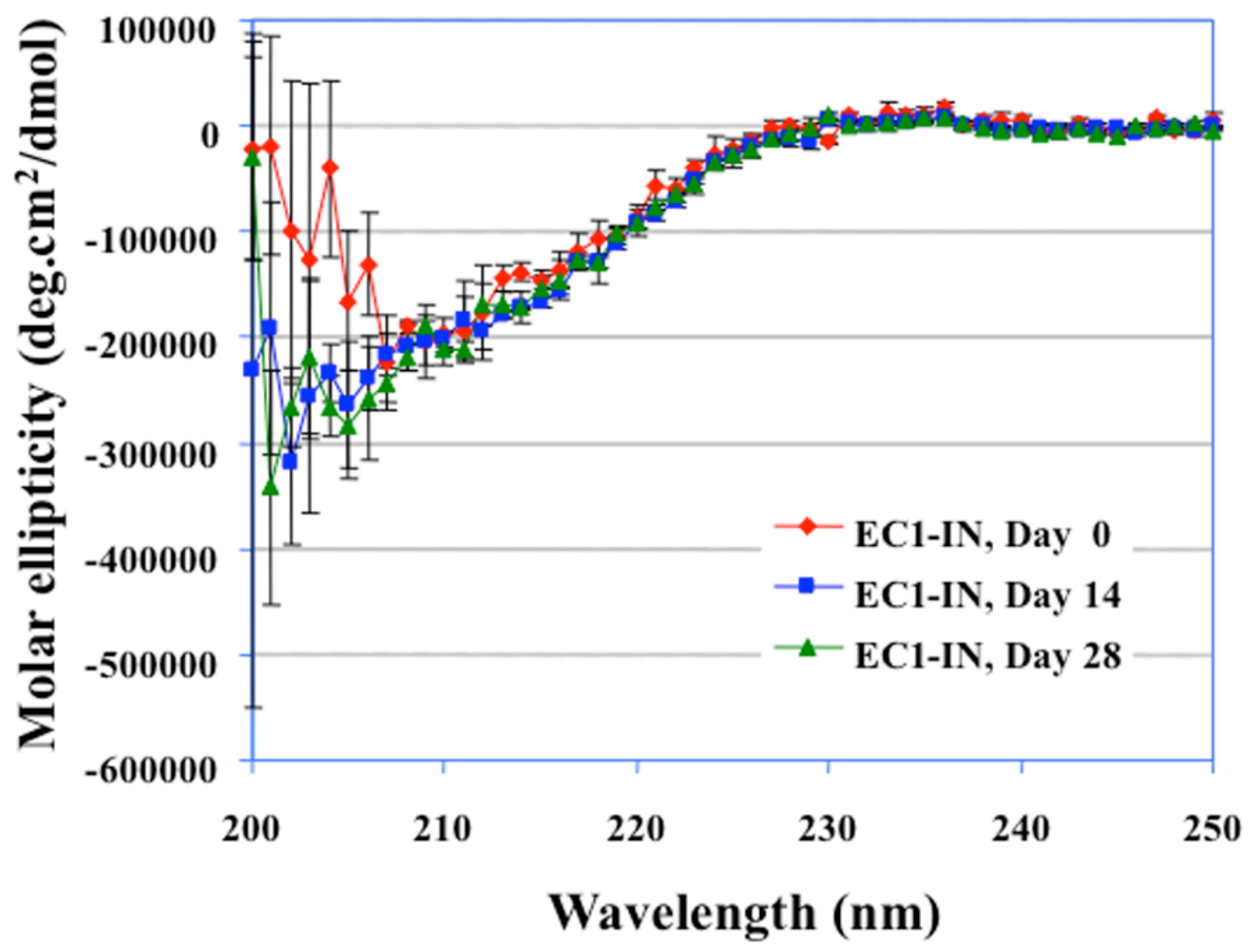

Fig. 6.

(A) Comparison of the CD spectra of EC1-IN and EC1 after their incubation at pH 3.0 for 14 days at $4{ }^{\circ} \mathrm{C}$. The $\mathrm{CD}$ spectrum of EC1-IN does not change substantially after 14 days, whereas the spectrum of EC1 changes upon 14 days incubation. (B) The CD spectra of EC1IN after its incubation at $\mathrm{pH} 7.0$ for 14 and 28 days at $4{ }^{\circ} \mathrm{C}$. The $\mathrm{CD}$ spectrum of EC1-IN does not change substantially after 14 and 28 days. (C) The CD spectra of EC1-IN after incubation at $\mathrm{pH} 9.0$ for 14 and 28 days at $4{ }^{\circ} \mathrm{C}$. The CD spectra of EC1-IN after 14 and 28 days are substantially different from those on day 0 . 


\section{Figure 7A}

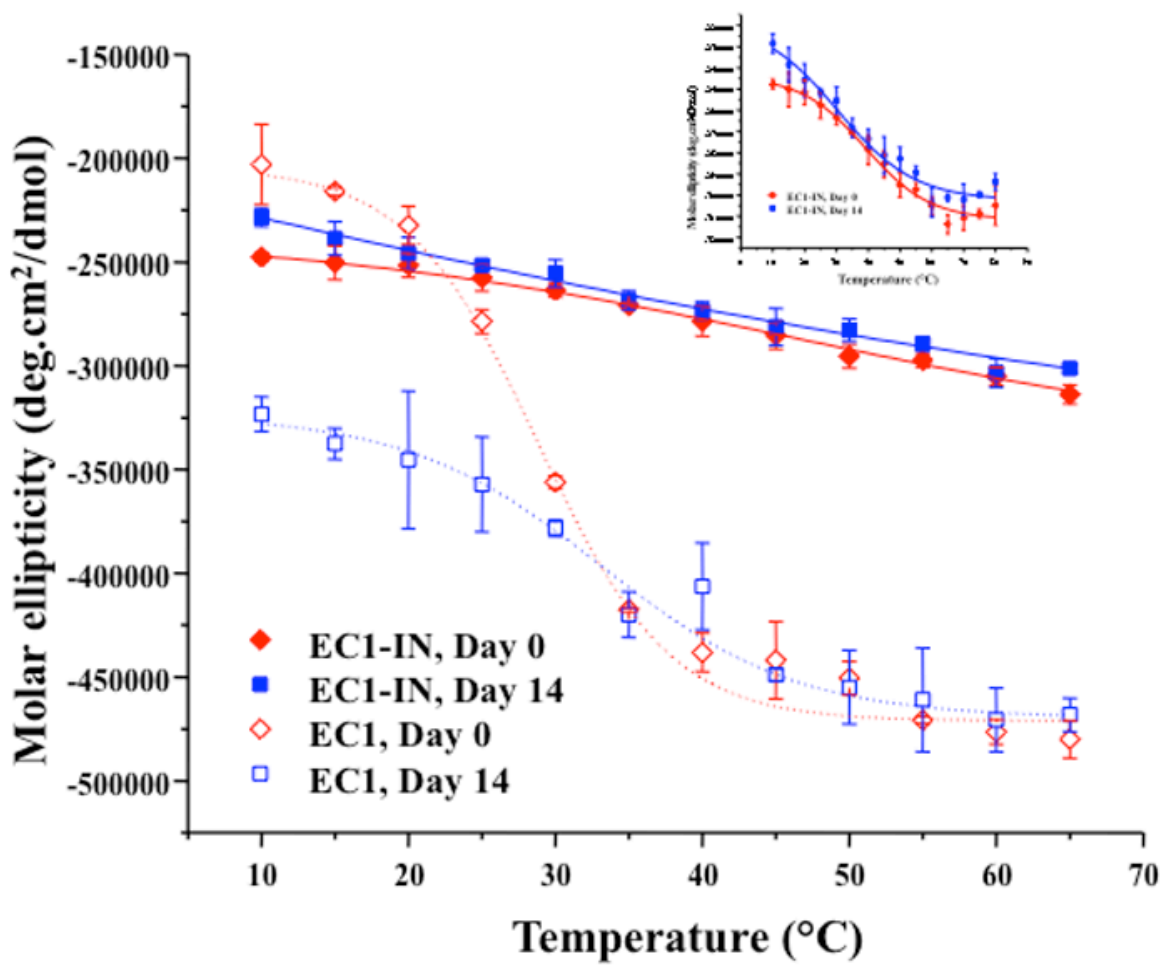

Figure 7B

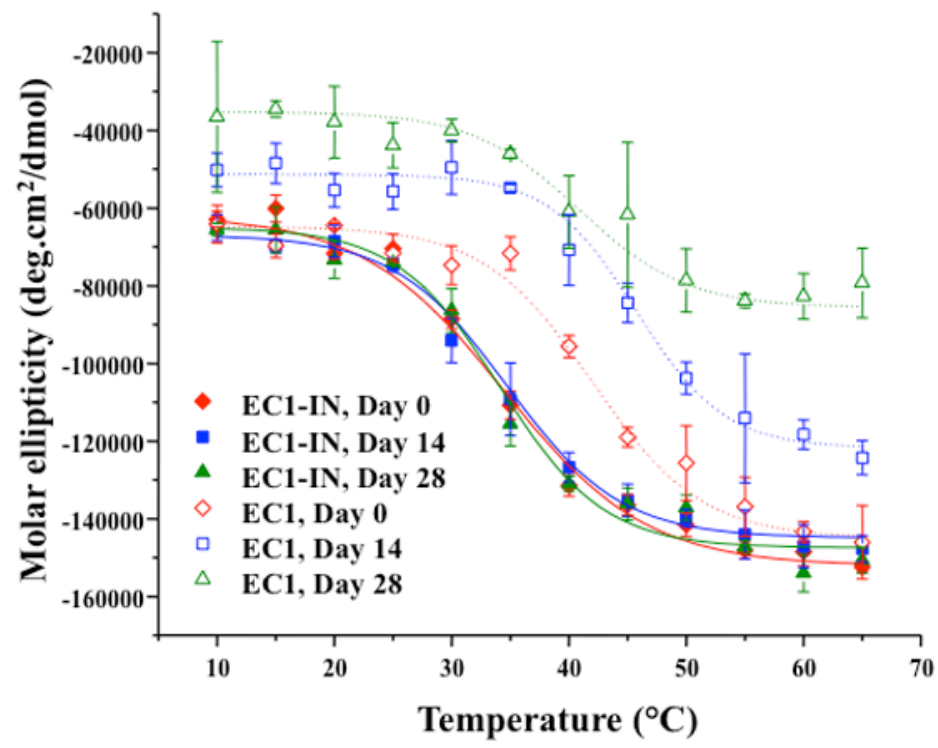

Int J Pharm. Author manuscript; available in PMC 2013 July 15. 
Figure 7C

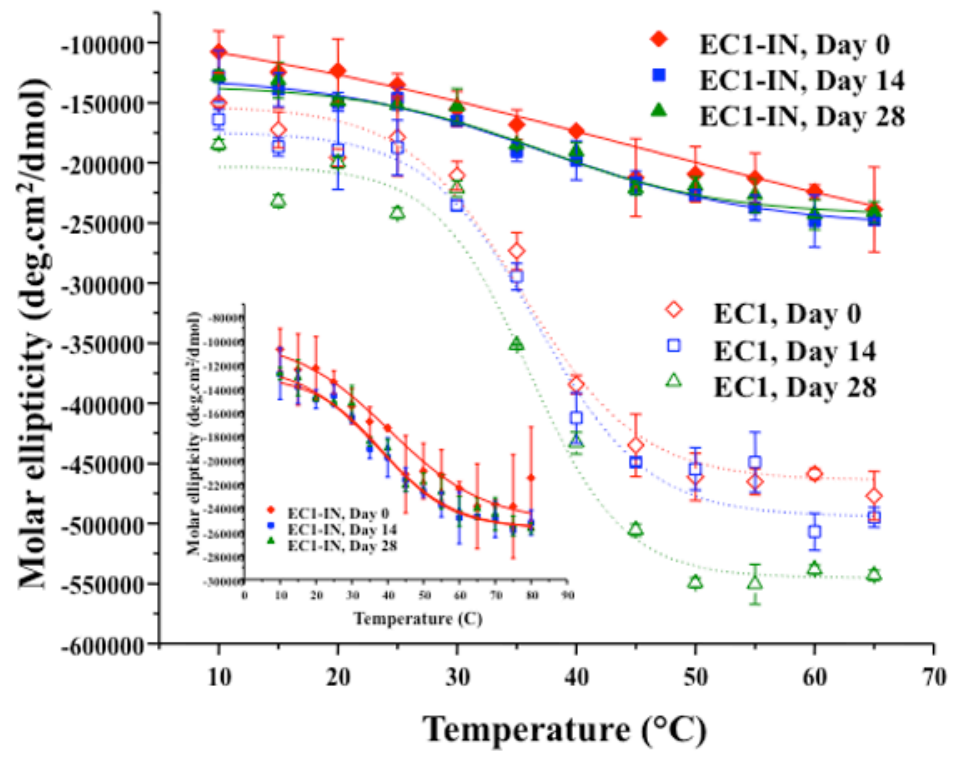

Fig. 7.

Comparison of the thermal unfolding curves of EC1-IN and EC1 proteins after incubation for 14 days at (A) $\mathrm{pH} 3.0,(\mathbf{B}) \mathrm{pH}$ 7.0, and (C) $\mathrm{pH}$ 9.0. There is a very small difference in the thermal unfolding curves of EC1-IN, whereas a clear change is seen in the thermal unfolding curve of EC1. The inset shows that the thermal unfolding curves of EC1-IN can be fitted to sigmoidal functions. Thermal unfolding profile of EC1 and EC1-IN measured by the CD signal at $218 \mathrm{~nm}$ after incubation for 0,14 , and 28 days at $4{ }^{\circ} \mathrm{C}$ at $\mathrm{pH}$ 7.0. There are limited differences in the thermal unfolding curves of EC1-IN, but dramatic differences are seen in the thermal unfolding curves of EC1. EC1 has a higher transition temperature than EC1-IN, indicating that EC1-IN is less stable to thermal unfolding than EC1. Thermal unfolding profile of EC1 and EC1-IN measured by the CD signal at $218 \mathrm{~nm}$ after incubation for 0,14 , and 28 days at $4{ }^{\circ} \mathrm{C}$ and $\mathrm{pH}$ 9.0. The thermal unfolding curves of EC1-IN are substantially different from those of EC1.The inset shows that the thermal unfolding of EC1-IN can be fitted to sigmoidal functions. 
Figure 8A

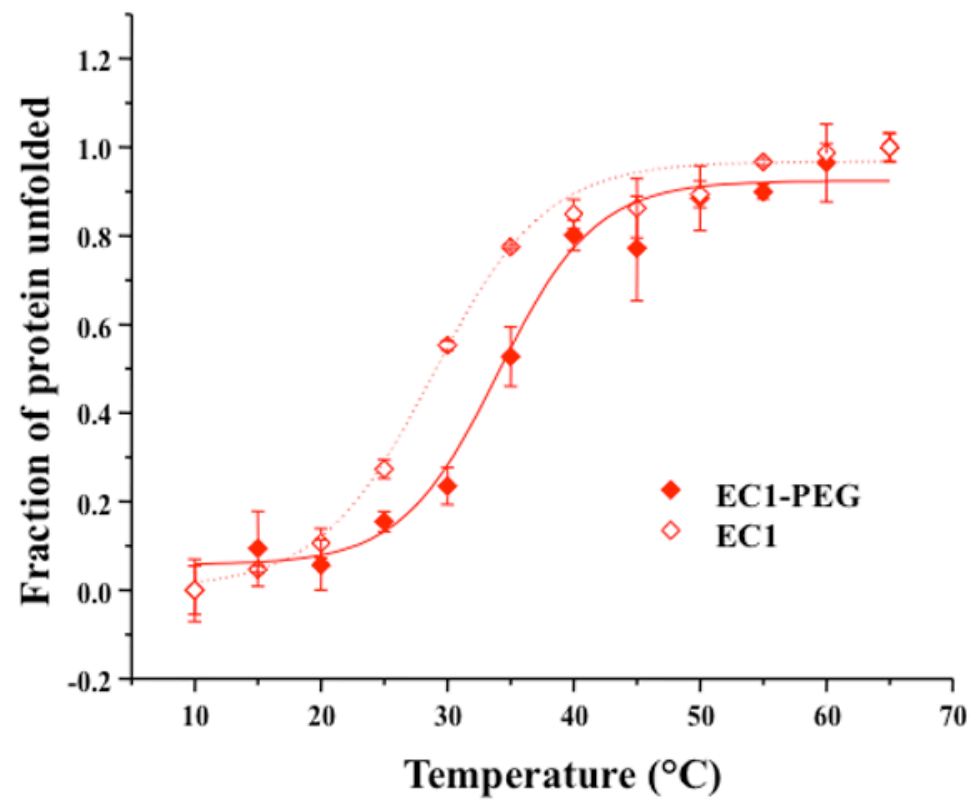

Figure $8 \mathrm{~B}$

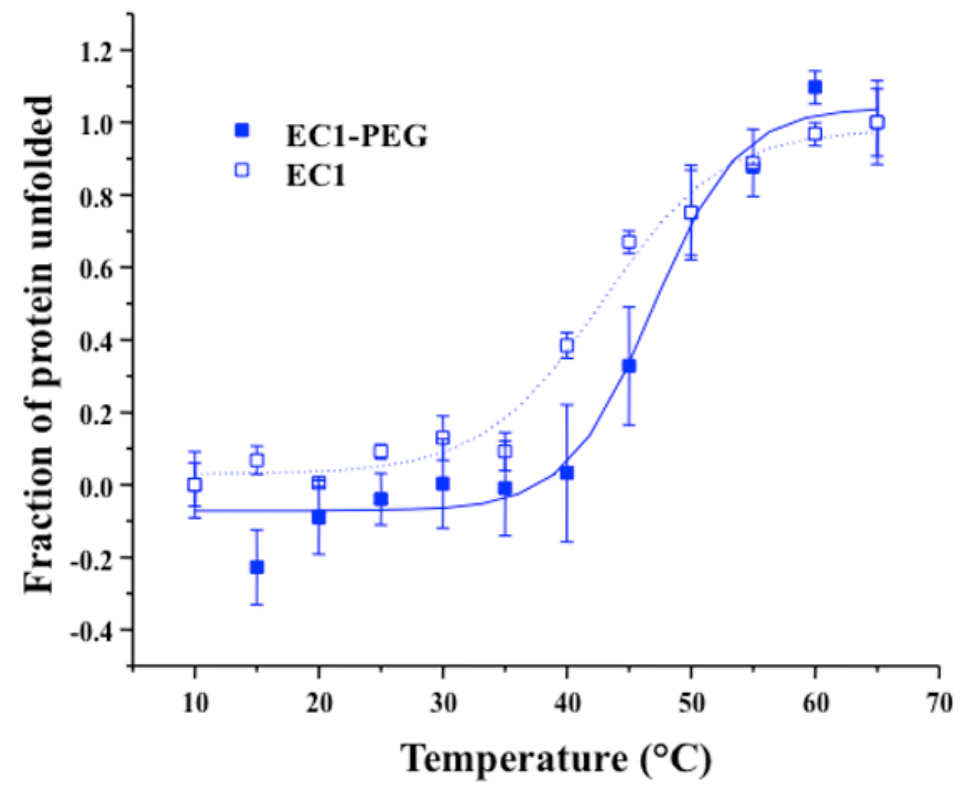

Int J Pharm. Author manuscript; available in PMC 2013 July 15. 


\section{Figure 8C}

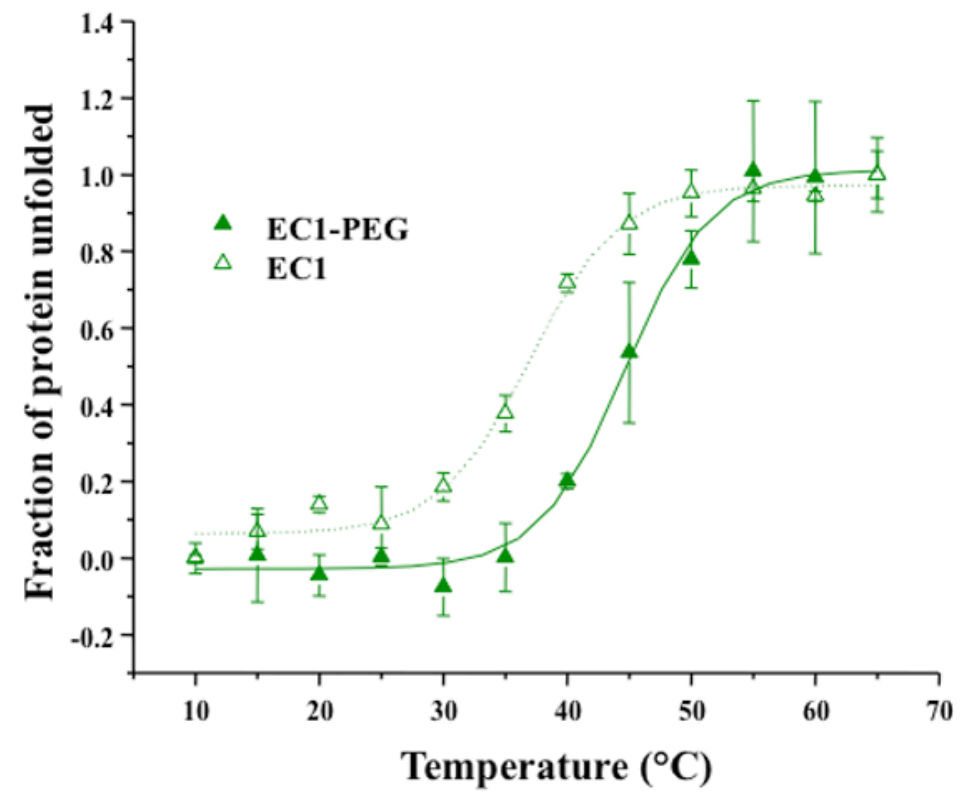

Figure 8D

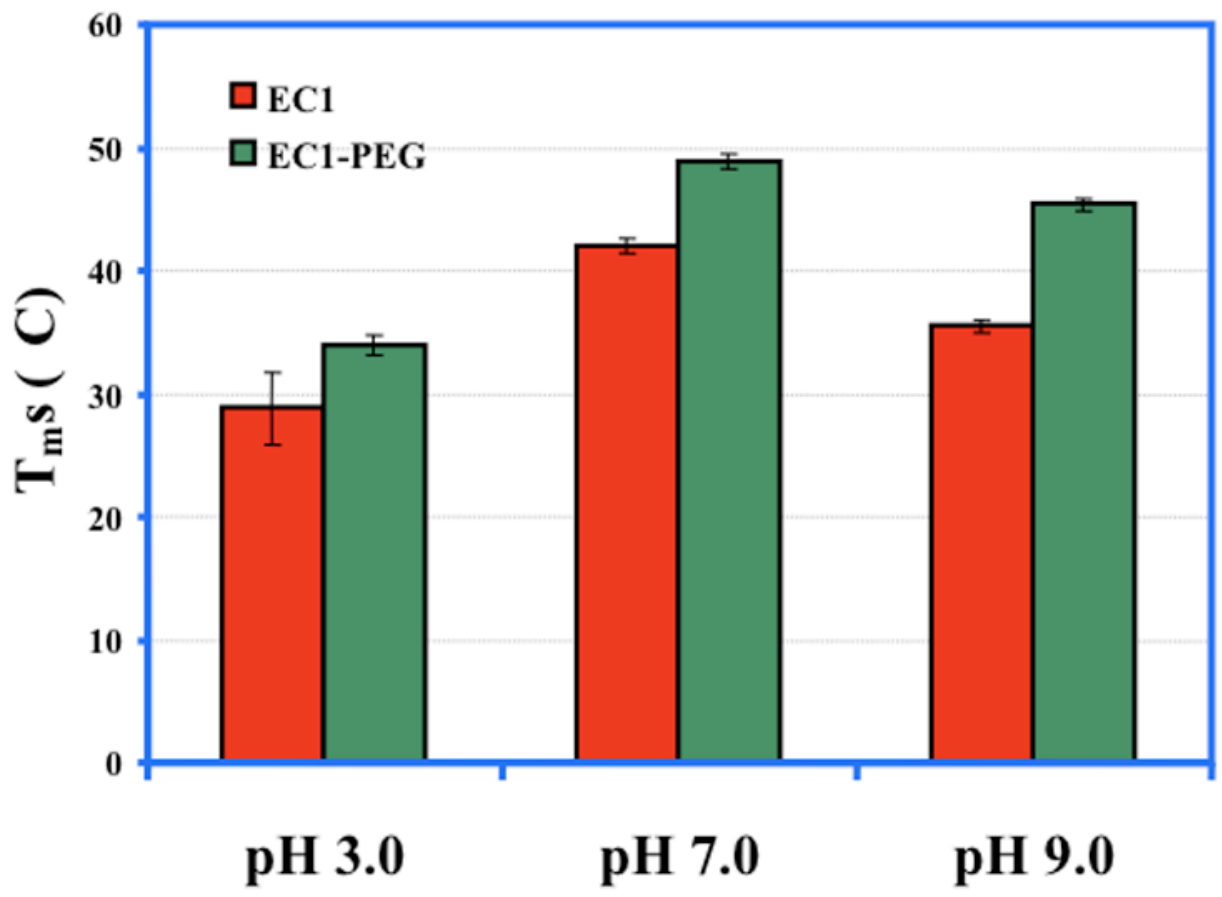

Fig. 8.

Thermal unfolding profile of EC1-PEG compared to that of EC1 obtained by plotting the $\mathrm{CD}$ signal at $218 \mathrm{~nm}$ against the corresponding temperature at (A) $\mathrm{pH} 3.0,(\mathbf{B}) \mathrm{pH} 7.0$, and 
(C) pH 9.0. (D) A comparison of the unfolding temperatures ( $\left.\mathrm{T}_{\mathrm{m}} \mathrm{s}\right)$ for EC1-PEG and EC1 at $\mathrm{pH}$ 3.0, 7.0, and 9.0 after fitting the $\mathrm{CD}$ thermal unfolding profiles to sigmoidal functions. 
Table 1

The wavelength at the maximum intensity fluorescence emission

\begin{tabular}{|l|l|l|c|}
\hline & EC1 $\boldsymbol{\lambda}$ in $\mathbf{~ m})$ & EC1-IN $(\boldsymbol{\lambda}$ in $\mathbf{~ m})$ & EC1-PEG $(\boldsymbol{\lambda}$ in $\mathbf{~ m m})$ \\
\hline pH 3.0 & & & \\
\hline Day 0 & $339.93 \pm 0.04$ & $340.61 \pm 0.08$ & $339.87 \pm 0.03$ \\
\hline Day 28 & $337.09 \pm 0.04$ & $338.91 \pm 0.06$ & \\
\hline pH 7.0 & & & \\
\hline Day 0 & $339.27 \pm 0.03$ & $342.13 \pm 0.05$ & $339.83 \pm 0.05$ \\
\hline Day 28 & $345.81 \pm 0.13$ & $341.21 \pm 0.05$ & \\
\hline pH 9.0 & & & \\
\hline Day 0 & $342.0 \pm 0.0$ & $343.0 \pm 1.0$ & $339.97 \pm 0.02$ \\
\hline Day 28 & $339.67 \pm 1.15$ & $341.67 \pm 0.58$ & \\
\hline
\end{tabular}

